Article

\title{
Critical Mineral Security in China: An Evaluation Based on Hybrid MCDM Methods
}

\author{
Long Zhang ${ }^{1, *}$, Wuliyasu Bai ${ }^{1}$, Jing Yu ${ }^{2}$, Linmao Ma ${ }^{2}$, Jingzheng Ren ${ }^{3}$, Weishi Zhang ${ }^{4}$ and \\ Yuanzheng Cui ${ }^{5}$ \\ 1 Business School, Xinyang Normal University, Xinyang 464000, China; wuliyasu666@163.com \\ 2 School of Economics and Management, China University of Geosciences, Wuhan 430074, China; \\ yujingcugwh@gmail.com (J.Y.); linmao@iti.sdu.dk (L.M.) \\ 3 Department of Industrial and Systems Engineering, The Hong Kong Polytechnic University, \\ Hong Kong, China; jzhren@polyu.edu.hk \\ 4 Research Center for Environment and Sustainable, Development of the China Civil Aviation, Civil Aviation \\ University of China, Tianjin 300300, China; zhangweishi@link.cuhk.edu.hk \\ 5 Institute of Land and Urban-rural Development, Zhejiang University of Finance and Economics, \\ Hangzhou 310018, China; cuiyuanzheng@163.com \\ * Correspondence: hbzhanglong876@163.com; Tel.: +86-376-639-0596
}

Received: 18 October 2018; Accepted: 6 November 2018; Published: 9 November 2018

check for updates

\begin{abstract}
With economic globalization, the supply-and-demand gap of China's minerals is becoming increasingly sharp, and the degree of dependence on imports is climbing, which poses a severe threat to the resource security for the country. From the perspectives of system and sustainable development, this paper develops a conceptual framework of mineral security, which is composed of five dimensions: availability, accessibility, technology and efficiency, sociability and governance, and environmental sustainability. Based on this framework, it constructs the evaluating metrics for measuring mineral security. Moreover, it employs the hybrid multiple criteria decision-making methods of Fuzzy analytic hierarchy process (AHP) and preference ranking organization method for enrichment evaluation (PROMETHEE) to assess the security performance for China's several critical minerals, namely iron, copper, aluminum, lead, zinc, and nickel, with respect to the period of 2001 to 2015. The result indicates that the critical minerals of China were at a low to moderate level of security. Iron, copper, and nickel were in an unsecure situation for their short supply in China, and showed a downswing trend. On the other hand, as the preponderant minerals, lead and zinc were at a relatively secure position and uprising; however, they were exhausting their superiority for the huge and rapid-growth economic demand. Aluminum, as a mineral that China seriously depends on for imports, also demonstrated an upward trend due to the successful management of diversity of importing sources.
\end{abstract}

Keywords: critical mineral security; China; multiple criterial decision-making; policy implications

\section{Introduction}

In recent years, the booming Chinese economy pushed the rapid increase of its demand for minerals and metals. Although it is a big developing country with abundant mineral resources, the domestic supply-and-demand gap of minerals is expanding, and the degree of dependence on mineral imports is climbing, which magnifies the risk of unexpected supply interruptions, and poses great threats to its mineral security $[1,2]$.

In fact, China was already the largest mineral consumer of the world for several years. In 2016, China's raw steel and pig-iron production accounted for $50 \%$ and $60 \%$, respectively, of world 
production, taking over half of the world's steel industry. On the other hand, it only produced $18.7 \%$ of iron ores (iron content) of the world that year, which means that China imported large amounts of iron ores to produce raw steel and pig iron [3]. The same thing happened for aluminum and copper, and even for China's superior minerals such as lead, zinc, nickel, tin, etc. The wide gap between supply and demand results in high dependence on foreign minerals and a high concentration of imports. In recent years, China's critical mineral dependence on imports peaked at $86.7 \%$ for iron ore, $69 \%$ for copper, $52 \%$ for aluminum, and $80 \%$ for nickel [4]. For instance, Australia, Brazil, and India almost cover three-quarters of China's iron ore imports [5]. The high dependence on foreign minerals and high concentration of import sources increase the risk and damage of sudden and unexpected mineral supply disruptions, which severely threaten China's mineral security. What is more, research proved that mining-related industries are some of the largest sources of environmental pollution from heavy metals, which can have a profound influence on water and soil resources, and lead to contamination of vegetables, crops, and even human health [6-9]. With the enlarged scale of mineral production in China, the mining industry brings an additional growing negative effect on the environment $[10,11]$. Therefore, despite the increasing demand for minerals, or the contamination caused by mineral production, they are the main threats for China's mineral security [12,13].

With such a set of challenges and threats, researchers and policy-makers are puzzled by the following questions:

(1) How should mineral security be defined under the background of sustainable development?

(2) How should national mineral security be measured and tracked?

(3) How did the energy security performance change during the past years?

(4) How can China enhance its national mineral security and minimize the related risks?

This study aimed to address all of these questions. It attempted to establish a framework of national mineral security, tried measuring it on a national scale in China, and analyzed its changes during the past years.

Although some studies already explored the measurement of mineral security or sustainability, they are just a small piece of the panorama of researches on sustainability [14], while the majority of researches on resource security or sustainability concern energy or water. For instance, Yu et al. evaluated the sustainable development of mineral resources of a mining city in China using a fuzzy integrated judgment model [15]. By developing the indicator of reserve entitlements to demand ratio, Hatayama and Tahara evaluated the supply risks of Japan with respect to 17 metals [16]. Chen et al. evaluated the perceptions of sustainable indicators in China by introducing a hybrid fuzzy iterative multi-criteria decision-making method (TODIM) [17].

Traditionally, mineral security is simply related to the reliable supply of minerals [18-21]. However, this definition is fragmented to some degree, because minerals are intricately associated with the society, economy, and environment throughout their life cycle [22]. Therefore, mineral security not only refers to the security of the mineral supply with respect to its availability and production, but also relates to the influence from the economy, society, environment, and even politics [22]. In addition to these elements, mineral security is also closed associated with mining technologies, and the continued innovation and investment in mining science and technology can serve as solutions to global mineral security [23].

Researchers underwent many studies to evaluate the interpretation of mineral security. A series of sustainable development indicators for mining and the mineral extraction industry were proposed and reviewed $[24,25]$. Furthermore, the framework for measuring the sustainability or security of the mining and mineral industry was investigated in many researches. Usually, the framework consists of economic, environmental, and social elements $[17,26]$, which are basic elements in the framework of sustainable development $[27,28]$. Based on these basic elements, a technical aspect was added to this framework, because the security or sustainable performance of minerals can be enhanced with the improvement of innovations in sciences and technology [29]. Moreover, it is also believed that political 
elements and governance on minerals can also benefit mineral security and sustainability; as such, they were also listed as import dimensions in this framework [30,31]. Therefore, some scholars summarized the framework of mineral sustainability with five pillars: ecological domain, technological domain, economic domain, social domain, and governance domain [25,32,33].

Despite the fact that scholars established an immaculate framework for mineral security or sustainability, they failed to conduct any empirical studies with the framework they proposed. Therefore, considering the significance of minerals and the alarming mineral security situation, this paper attempted to develop a conceptual framework of mineral security based on existing researches, before employing the proposed framework to evaluate the security performance of several minerals of China, and extracting some policy implications for enhancing mineral security performance.

\section{Materials and Methods}

To evaluate China's mineral security, we established a conceptual framework and metrics, and propose the applicable methods in this section.

\subsection{Dimensions and Metrics}

In order to propose a comprehensive yet practicable and parsimonious framework for assessing national mineral security, this paper designed the dimensions and indicators of mineral security based on existing researches $[25,32,33]$. The designed framework in this paper consists of five dimensions: availability, accessibility, technology and efficiency, sociability and governance, and environmental sustainability. The five dimensions are further decomposed into 12 components, which are measured by 26 metrics, as shown in Table 1, where the relevant data sources are also listed. In fact, these five dimensions were also validated by a series of researches on energy security. For instance, the results of some workshop discussions [34], literature reviews [35], surveys of public attitudes [36], and qualitative or quantitative researches on energy security measurement [37-40] also support the framework of these five dimensions.

Table 1. Dimensions, components, and metrics of mineral security.

\begin{tabular}{|c|c|c|c|c|}
\hline Dimensions & Components & Metrics & Explanation & Data source \\
\hline \multirow{6}{*}{$\mathrm{A}_{1}:$ Availability } & \multirow{3}{*}{$\begin{array}{l}\mathrm{A}_{11}: \text { Mineral } \\
\text { potential }\end{array}$} & $\begin{array}{l}\mathrm{I}_{1}: \text { Reserve to } \\
\text { production ratio }\end{array}$ & Mineral reserves/mineral production & $\begin{array}{l}\text { China Mining } \\
\text { Yearbook }\end{array}$ \\
\hline & & $\begin{array}{l}\mathrm{I}_{2}: \text { Per capita mineral } \\
\text { reserves }\end{array}$ & Mineral reserves/total population & $\begin{array}{l}\text { China Mining } \\
\text { Yearbook }\end{array}$ \\
\hline & & $\begin{array}{l}\mathrm{I}_{3}: \text { Ratio of domestic } \\
\text { mineral reserves to } \\
\text { world total }\end{array}$ & $\begin{array}{l}\text { Domestic mineral reserves/world } \\
\text { total mineral reserves }\end{array}$ & $\begin{array}{l}\text { Mineral } \\
\text { Commodity } \\
\text { Summary }\end{array}$ \\
\hline & \multirow{3}{*}{$\begin{array}{l}\mathrm{A}_{12}: \text { Mineral } \\
\text { production }\end{array}$} & $\mathrm{I}_{4}:$ Self-sufficiency & $\begin{array}{l}\text { Total mineral production/total } \\
\text { mineral consumption }\end{array}$ & $\begin{array}{l}\text { China Mineral } \\
\text { Resources }\end{array}$ \\
\hline & & $\begin{array}{l}\mathrm{I}_{5}: \text { Production } \\
\text { centralization }\end{array}$ & $\begin{array}{l}\text { Number of middle-large mineral } \\
\text { companies/number of total mineral } \\
\text { companies }\end{array}$ & $\begin{array}{l}\text { China Mining } \\
\text { Yearbook }\end{array}$ \\
\hline & & $\begin{array}{l}\mathrm{I}_{6}: \text { Ratio of domestic } \\
\text { mineral production } \\
\text { to world total }\end{array}$ & $\begin{array}{l}\text { Domestic mineral production/world } \\
\text { total mineral production }\end{array}$ & $\begin{array}{l}\text { Mineral } \\
\text { Commodity } \\
\text { Summary }\end{array}$ \\
\hline \multirow{3}{*}{$\begin{array}{l}\mathrm{A}_{2}: \\
\text { Accessibility }\end{array}$} & \multirow{2}{*}{$\begin{array}{l}\mathrm{A}_{21}: \text { Import } \\
\text { security }\end{array}$} & $\begin{array}{l}\mathrm{I}_{7}: \text { Concentration of } \\
\text { importing sources }\end{array}$ & $S W I=\sum_{i=1}^{m} p_{i} \ln \left(p_{i}\right)$ & $\begin{array}{l}\text { China Mining } \\
\text { Yearbook }\end{array}$ \\
\hline & & $\mathrm{I}_{8}:$ Mineral prices & $\begin{array}{l}\text { Mineral prices in the international } \\
\text { mineral market }\end{array}$ & $\begin{array}{l}\text { London Metal } \\
\text { Exchange }\end{array}$ \\
\hline & $\begin{array}{l}\mathrm{A}_{22}: \text { Transport } \\
\text { security }\end{array}$ & $\begin{array}{l}\mathrm{I}_{9}: \text { Safety of } \\
\text { transport routes }\end{array}$ & $\begin{array}{l}\text { Actual and attempted piracy attacks } \\
\text { around the world }\end{array}$ & $\begin{array}{l}\text { International } \\
\text { Maritime } \\
\text { Organization }\end{array}$ \\
\hline
\end{tabular}


Table 1. Cont.

\begin{tabular}{|c|c|c|c|c|}
\hline Dimensions & Components & Metrics & Explanation & Data source \\
\hline \multirow{4}{*}{$\begin{array}{l}\mathrm{A}_{3}: \text { Technology } \\
\text { and efficiency }\end{array}$} & \multirow{2}{*}{$\begin{array}{l}\mathrm{A}_{31}: \text { Mining } \\
\text { technologies }\end{array}$} & $\begin{array}{l}\mathrm{I}_{10} \text { : Mining } \\
\text { technology } \\
\text { innovations }\end{array}$ & $\begin{array}{l}\text { Scientific and technological } \\
\text { achievements registered in Ministry } \\
\text { of Land and Resources }\end{array}$ & $\begin{array}{l}\text { China Gazette } \\
\text { of Land and } \\
\text { Resources }\end{array}$ \\
\hline & & $\begin{array}{l}\mathrm{I}_{11}: \text { Newly } \\
\text { discovered reserves }\end{array}$ & $\begin{array}{l}\text { Newly discovered reserves/yearly } \\
\text { mineral production }\end{array}$ & $\begin{array}{l}\text { China Gazette } \\
\text { of Land and } \\
\text { Resources }\end{array}$ \\
\hline & \multirow{2}{*}{$\begin{array}{l}\mathrm{A}_{32}: \text { Mineral } \\
\text { utilization }\end{array}$} & $\mathrm{I}_{12}:$ Mineral intensity & $\begin{array}{l}\text { Volume of mineral } \\
\text { consumption/Gross Domestic } \\
\text { Product }\end{array}$ & $\begin{array}{l}\text { China Mining } \\
\text { Yearbook }\end{array}$ \\
\hline & & $\begin{array}{l}\mathrm{I}_{13}: \text { Comprehensive } \\
\text { utilization of } \\
\text { minerals }\end{array}$ & $\begin{array}{l}\text { Output from comprehensive } \\
\text { utilization of minerals/total mining } \\
\text { output }\end{array}$ & $\begin{array}{l}\text { China Mining } \\
\text { Yearbook }\end{array}$ \\
\hline \multirow{5}{*}{$\begin{array}{l}\mathrm{A}_{4}: \text { Sociability } \\
\text { and governance }\end{array}$} & \multirow{2}{*}{$\mathrm{A}_{41}$ : Employment } & $\begin{array}{l}\mathrm{I}_{14}: \text { Ratio of mining } \\
\text { workers in total } \\
\text { employment }\end{array}$ & $\begin{array}{l}\text { Number of mining workers/total } \\
\text { social employment }\end{array}$ & $\begin{array}{l}\text { China National } \\
\text { Bureau of } \\
\text { Statistics }\end{array}$ \\
\hline & & $\begin{array}{l}\mathrm{I}_{15}: \text { Wage level of } \\
\text { mining workers }\end{array}$ & $\begin{array}{l}\text { Average wages of mining } \\
\text { workers/average wages of total social } \\
\text { employment }\end{array}$ & $\begin{array}{l}\text { China National } \\
\text { Bureau of } \\
\text { Statistics }\end{array}$ \\
\hline & \multirow{2}{*}{$\begin{array}{l}\mathrm{A}_{42}: \text { Investment } \\
\text { and expenditure }\end{array}$} & $\begin{array}{l}\mathrm{I}_{16}: \text { Government } \\
\text { investment on } \\
\text { mining exploration }\end{array}$ & $\begin{array}{l}\text { Government investment on mining } \\
\text { exploration/Gross Domestic Product }\end{array}$ & $\begin{array}{l}\text { China Mining } \\
\text { Yearbook }\end{array}$ \\
\hline & & $\begin{array}{l}\mathrm{I}_{17}: \text { Expenditure on } \\
\text { mining environment } \\
\text { restoration }\end{array}$ & $\begin{array}{l}\text { Expenditure on mining environment } \\
\text { restoration/total government } \\
\text { expenditure }\end{array}$ & $\begin{array}{l}\text { China Mineral } \\
\text { Resources } \\
\text { Report }\end{array}$ \\
\hline & $\begin{array}{l}\mathrm{A}_{43}: \text { Governance } \\
\text { efficiency }\end{array}$ & $\begin{array}{l}\mathrm{I}_{18}: \text { Cases of illegal } \\
\text { mining activities }\end{array}$ & $\begin{array}{l}\text { Illegal cases of mining investigation } \\
\text { and exploitation }\end{array}$ & $\begin{array}{l}\text { China Mining } \\
\text { Yearbook }\end{array}$ \\
\hline \multirow{8}{*}{$\begin{array}{l}\mathrm{A}_{5}: \\
\text { Environmental } \\
\text { sustainability }\end{array}$} & \multirow{2}{*}{$\begin{array}{l}\mathrm{A}_{51}: \text { Land } \\
\text { environment }\end{array}$} & $\begin{array}{l}\mathrm{I}_{19}: \text { Intensity of } \\
\text { industrial solid } \\
\text { waste emissions }\end{array}$ & $\begin{array}{l}\text { Volume of industrial solid waste } \\
\text { emissions/Gross Domestic Product }\end{array}$ & $\begin{array}{l}\text { China National } \\
\text { Bureau of } \\
\text { Statistics }\end{array}$ \\
\hline & & $\begin{array}{l}\mathrm{I}_{20}: \text { Ratio of } \\
\text { industrial solid } \\
\text { waste utilized }\end{array}$ & $\begin{array}{l}\text { Volume of utilized industrial solid } \\
\text { waste/volume of industrial solid } \\
\text { waste emissions }\end{array}$ & $\begin{array}{l}\text { China National } \\
\text { Bureau of } \\
\text { Statistics }\end{array}$ \\
\hline & \multirow{3}{*}{$\begin{array}{l}\mathrm{A}_{52}: \text { Water } \\
\text { environment }\end{array}$} & $\begin{array}{l}\mathrm{I}_{21}: \text { Intensity of } \\
\text { industrial waste } \\
\text { water emissions }\end{array}$ & $\begin{array}{l}\text { Volume of industrial waste water } \\
\text { emissions/Gross Domestic Product }\end{array}$ & $\begin{array}{l}\text { China National } \\
\text { Bureau of } \\
\text { Statistics }\end{array}$ \\
\hline & & $\begin{array}{l}\mathrm{I}_{22} \text { : Intensity of } \\
\text { industrial COD } \\
\text { emissions }\end{array}$ & $\begin{array}{l}\text { Volume of industrial COD } \\
\text { emissions/Gross Domestic Product }\end{array}$ & $\begin{array}{l}\text { China National } \\
\text { Bureau of } \\
\text { Statistics }\end{array}$ \\
\hline & & $\begin{array}{l}\mathrm{I}_{23} \text { : Intensity of } \\
\text { industrial } \mathrm{NH}_{3}-\mathrm{N} \\
\text { emissions }\end{array}$ & $\begin{array}{l}\text { Volume of industrial ammonia } \\
\text { nitrogen emissions/Gross Domestic } \\
\text { Product }\end{array}$ & $\begin{array}{l}\text { China National } \\
\text { Bureau of } \\
\text { Statistics }\end{array}$ \\
\hline & \multirow{3}{*}{$\begin{array}{l}\mathrm{A}_{53}: \text { Air } \\
\text { environment }\end{array}$} & $\begin{array}{l}\mathrm{I}_{24} \text { : Intensity of } \\
\text { industrial } \mathrm{SO}_{2} \\
\text { emissions }\end{array}$ & $\begin{array}{l}\text { Volume of industrial } \mathrm{SO}_{2} \\
\text { emissions/Gross Domestic Product }\end{array}$ & $\begin{array}{l}\text { China National } \\
\text { Bureau of } \\
\text { Statistics }\end{array}$ \\
\hline & & $\begin{array}{l}\mathrm{I}_{25}: \text { Intensity of } \\
\text { industrial soot and } \\
\text { dust emissions }\end{array}$ & $\begin{array}{l}\text { Volume of industrial soot and dust } \\
\text { emissions/Gross Domestic Product }\end{array}$ & $\begin{array}{l}\text { China National } \\
\text { Bureau of } \\
\text { Statistics }\end{array}$ \\
\hline & & $\begin{array}{l}\mathrm{I}_{26}: \text { Intensity of } \mathrm{NOx} \\
\text { emissions }\end{array}$ & $\begin{array}{l}\text { Volume of industrial solid wastes } \\
\text { emissions/Gross Domestic Product }\end{array}$ & $\begin{array}{l}\text { China National } \\
\text { Bureau of } \\
\text { Statistics }\end{array}$ \\
\hline
\end{tabular}

\subsubsection{Availability}

Availability refers to the geographical existence of mineral resources distributed within the territory of a country, as well as its ore production used to support its economic development. This dimension consists of two components: mineral potential and mineral production. In order to measure these two components, six metrics were designed. Mineral potential was measured by three indicators: reserve to production ratio, per capita mineral reserves, and ratio of domestic mineral 
reserves to world total. Mineral production was measured by another three indicators: self-sufficiency, ratio of domestic mineral production to world total, and production centralization.

\subsubsection{Accessibility}

In order to satisfy the demand for minerals, a country usually has to seek mineral supply from external sources. The dimension of accessibility exactly measures the external supply security of mineral resources, and two components were considered in this dimension: mineral import security and mineral transport security. Here, the concentration of importing sources and the mineral price in the international market were used to measure import security, while safety of transport routes was designed to measure transport security.

\subsubsection{Technology Efficiency}

The dimension of technology and efficiency represents the development and progress of mining and mineral technologies, as well as the efficiency of mineral utilization. Therefore, two components were included in this dimension: mining technologies and mineral utilization. The metrics used to measure mining technologies were designed as mining technology innovations and newly discovered reserves, and those used to measure mineral utilization were mineral intensity and the comprehensive utilization of minerals.

\subsubsection{Sociability and Governance}

This dimension relates to the social and political factors that may affect mineral security. Here, we decomposed this dimension into three components: employment, investment and expenditure, and governance efficiency. Among them, the component of employment was measured by two indicators: proportion of mining workers in total social employment and wage level of mining workers. The component of investment and expenditure included the investment both on mineral exploration and mining environmental restoration. Governance efficiency was represented by the resolved illegal exploration and extraction cases that year.

\subsubsection{Environmental Sustainability}

The dimension of environmental sustainability regards the influence of the mineral and mining industry on environment. As a high-pollution industry, mining extraction and processing is extremely devastating to the quality of air, water, and soil, which can cause great damage to the living things on the earth. Therefore, air quality, land use, and water environment were the aspects considered in the dimension of environmental sustainability. Here, we used three components to represent environmental sustainability: land environment, water environment, and air environment. Among them, land environment was measured by industrial solid waste emitted and utilized, water environment was measured by intensity of industrial waste water, Chemical Oxygen Demand (COD), and $\mathrm{NH}_{3}-\mathrm{N}$ emissions, and air environment was measured by intensity of industrial $\mathrm{SO}_{2}$, soot and dust, and Nitrogen Oxides (NOx) emissions.

\subsection{Methods}

Since mineral security measurement is a multidimensional problem with some uncertainty and ambiguity, multi-criteria decision-making methods are considered as the most appropriate tools or techniques for optimizing solutions to assess sustainable development in the mining and mineral industry [41,42]. In this paper, the fuzzy analytical hierarchal process (Fuzzy AHP) and preference ranking organization method for enrichment evaluations (PROMETHEE) were used to measure China's national mineral security. 
These two methods can deal with problems of incomplete information and uncertainties [43]. To be specific, AHP is frequently employed to acquire the weight of criteria by collecting and analyzing the opinions and preference of experts on the problem, which is a very powerful tool for solving multi-level and complex multi-criteria decision-making problems [44]. In order to improve its robustness and flexibility to process nonlinear variables, it was combined with fuzzy theory [45]. The method of fuzzy AHP is simple in calculation and effective in dealing with uncertainties in multi-criteria decision-making problems by using a membership function to compute the degree of membership that a given variable belongs to [46,47]. PROMETHEE, a popular method and a recently developed multi-criteria decision-making technique, is very practical and useful in determining the priority of a group of alternatives $[48,49]$. The method of PROMETHEE relies on six types of preference functions to convert the difference between two actions for a specific criterion into a preference degree using two parameters: indifference threshold and preference threshold [50,51].

\subsubsection{Fuzzy AHP}

Fuzzy AHP is usually used to determine the weight of criteria and compare the performance of the alternatives with respect to each criterion [52]. Before conducting fuzzy AHP, it is necessary to define the problem first. In order to do this, a hierarchy structure model should be developed. Usually, three levels are included in this hierarchy model: the top level defines the overall goal of this assessment, the second level identifies the criteria for this assessment, and the bottom level provides some alternatives for achieving this overall goal. Here, in our assessment, the overall goal was mineral security, which was decomposed into five dimensions, and, in order to represent these five dimensions, 26 metrics were selected as the criteria for measuring them, while the mineral security of each year represents the alternatives.

The procedure of fuzzy AHP is conducted along the following steps:

Step 1: Pairwise comparisons of the criteria are made according to their relative importance with respect to the overall goal, and the importance of the alternatives with respect to each criterion using fuzzy numbers. In this study, we relied on the linguistic term and corresponding fuzzy numbers (as presented in Table 2) to make pairwise comparisons.

Step 2: The comparison matrix is established based on the pairwise comparison in Step 1. Let us assume that a total of $n$ criteria are included in the decision unit, with the $i_{t h}$ criteria represented by $C_{i}$. Then, the fuzzy comparison matrix can be obtained as shown below.

$$
\widetilde{M}=\left|\begin{array}{cccc}
\widetilde{1} & \widetilde{m}_{12} & \cdots & \widetilde{m}_{1 n} \\
\widetilde{m}_{21} & \widetilde{1} & \cdots & \widetilde{m}_{2 n} \\
\vdots & \vdots & \ddots & \vdots \\
\widetilde{m}_{n 1} & \widetilde{m}_{n 2} & \cdots & \widetilde{\widetilde{1}}
\end{array}\right|=\left|\begin{array}{cccc}
\widetilde{1} & \widetilde{m}_{12} & \cdots & \widetilde{m}_{1 n} \\
1 / \widetilde{m}_{12} & \widetilde{1} & \cdots & \widetilde{m}_{2 n} \\
\vdots & \vdots & \ddots & \vdots \\
1 / \widetilde{m}_{1 n} & 1 / \widetilde{m}_{2 n} & \cdots & \widetilde{\widetilde{1}}
\end{array}\right|,
$$

where $\widetilde{m}_{i j}=\left(m_{i j}^{L}, m_{i j}^{M}, m_{i j}^{U}\right)$ is the triangular fuzzy number, $m_{i j}^{L}$ represents the lowest possible value, $m_{i j}^{U}$ represents the most likely value, and $m_{i j}^{M}$ represents the highest possible value.

Table 2. The linguistic terms and corresponding fuzzy scales.

\begin{tabular}{cc}
\hline Linguistic Scales & Triangular Fuzzy Scales \\
\hline Equally important (E) & $(1,1,1)$ \\
Weakly important (W) & $(1 / 2,1,3 / 2)$ \\
Moderately important (M) & $(1,3 / 2,2)$ \\
Fairly strongly important (F) & $(3 / 2,2,5 / 2)$ \\
Very strongly important (V) & $(2,5 / 2,3)$ \\
Absolutely important (A) & $(5 / 2,3,7 / 2)$ \\
Reciprocals of these & Reciprocals of the fuzzy numbers \\
\hline
\end{tabular}


Step 3: The value of fuzzy synthetic extent is computed with respect to the $i_{t h}$ criterion, which is defined as

$$
S_{i}=\sum_{j=1}^{n} \widetilde{m}_{i j} \otimes\left[\sum_{i=1}^{n} \sum_{j=1}^{n} \widetilde{m}_{i j}\right]^{-1},
$$

where

$$
\begin{gathered}
\sum_{j=1}^{n} \widetilde{m}_{i j}=\left(\sum_{j=1}^{n} m_{i j}^{L}, \sum_{j=1}^{n} m_{i j}^{M}, \sum_{j=1}^{n} m_{i j}^{U}\right), i, j=1,2, \cdots, n, \\
{\left[\sum_{i=1}^{n} \sum_{j=1}^{n} \widetilde{m}_{i j}\right]^{-1}=\left(\frac{1}{\sum_{i=1}^{n} \sum_{j=1}^{n} m_{i j}^{L}}, \frac{1}{\sum_{i=1}^{n} \sum_{j=1}^{n} m_{i j}^{M}}, \frac{1}{\sum_{i=1}^{n} \sum_{j=1}^{n} m_{i j}^{U}}\right) .}
\end{gathered}
$$

It is worth noting that $S_{i}=\left(S_{i}^{L}, S_{i}^{M}, S_{i}^{U}\right)$ is the value of the fuzzy synthetic extent with respect to the $i_{t h}$ criterion, and $S_{i}^{L}, S_{i}^{M}$, and $S_{i}^{U}$ are the three elements of the triangular number of $S_{i}$.

Step 4: The degree of possibility of $S_{i}=\left(S_{i}^{L}, S_{i}^{M}, S_{i}^{U}\right) \geq S_{j}=\left(S_{j}^{L}, S_{j}^{M}, S_{j}^{U}\right)$ is calculated, which is defined as follows:

$$
\widetilde{p}_{i j}=V\left(S_{i} \geq S_{j}\right)=\left\{\begin{array}{cl}
1 & S_{j}^{M} \geq S_{i}^{M} \\
0 & S_{j}^{L} \geq S_{i}^{U} . \\
\frac{S_{j}^{L}-S_{i}^{U}}{\left(S_{i}^{M}-S_{i}^{U}\right)-\left(S_{j}^{M}-S_{j}^{L}\right)} & \text { otherwise }
\end{array}\right.
$$

Step 5: The possibility matrix is determined, which is used to describe the relative significance of each pair of criteria using the corresponding value of the fuzzy synthetic extent as shown in Equation (6).

$$
\widetilde{P}=\left|\begin{array}{cccc}
/ & \widetilde{p}_{12} & \cdots & \widetilde{p}_{1 n} \\
\widetilde{p}_{21} & / & \cdots & \widetilde{p}_{2 n} \\
\vdots & \vdots & \ddots & \vdots \\
\widetilde{p}_{n 1} & \widetilde{p}_{n 2} & \cdots & /
\end{array}\right|
$$

Step 6: The degree of possibility for the fuzzy synthetic extent is obtained with respect to each criterion to be greater than that for all the other criteria. For instance, the degree of possibility for the fuzzy synthetic extent with respect the $i_{t h}$ criterion is greater than that with respect to all the other criteria, and can be defined as follows:

$$
V\left(S_{i} \geq S_{1}, S_{2}, \cdots, S_{k}, \cdots, S_{n}\right)=V\left(S_{i} \geq S_{1}\right) \text { and } V\left(S_{i} \geq S_{2}\right) \text { and } \ldots \text { and } V\left(S_{i} \geq S_{n}\right)=\min V\left(S_{i} \geq S_{k}\right),
$$

where $k=1,2, \cdots, n$ and $k \neq i$.

Assume that $d^{\prime}\left(C_{i}\right)=\min V\left(S_{i} \geq S_{k}\right)$; then, the weight vector for the $n$ criteria can be defined by Equation (9).

$$
W^{\prime}=\left(d^{\prime}\left(C_{1}\right), d^{\prime}\left(C_{2}\right), \cdots, d^{\prime}\left(C_{n}\right)\right)^{T} .
$$

Step 7: The weight vectors are normalized, which are written as

$$
W=\left(d\left(C_{1}\right), d\left(C_{2}\right), \cdots, d\left(C_{n}\right)\right)^{T}=\left(w_{1}, w_{2}, \cdots, w_{n}\right),
$$

where

$$
d\left(C_{i}\right)=\frac{d^{\prime}\left(C_{i}\right)}{\sum_{i=1}^{n} d^{\prime}\left(C_{i}\right)}
$$




\subsubsection{PROMETHEE}

PROMETHEE prioritizes the alternatives by relying on the positive and negative outranking flows of each alternative based on the pairwise comparison of the alternatives with respect to each criterion, and the process is described below.

Step 1: The decision matrix is established and normalized. Let us assume that there are a total of $m$ alternatives and $n$ criteria in the decision problem, and $a_{i j}$ donates the attribute value of the $i_{t h}$ alternative with respect to the $j_{t h}$ criterion; then, the decision matrix can be represented by $A=\left(a_{i j}\right)_{m \times n}$. In order to eliminate the dimensional effect of the metrics, the benefit and cost type criteria are normalized by Equations (11) and (12), respectively; then, the normalized decision matrix can be donated by $X=\left(x_{i j}\right)_{m \times n}$, where $x_{i j}$ is the normalized value of the $i_{t h}$ alternative with respect to the $j_{\text {th }}$ criterion.

$$
\begin{aligned}
& x_{i j}=\frac{a_{i j}-\max a_{j}}{\max a_{j}-\min a_{j}}, \\
& x_{i j}=\frac{\max a_{j}-a_{i j}}{\max a_{j}-\min a_{j}},
\end{aligned}
$$

where $\max a_{j}$ and $\min a_{j}$ represent the maximum and minimum values of all the alternatives with respect to the $j_{t h}$ criterion.

Step 2: The deviations are computed based on pairwise comparisons according to Equation (13), which donates the preference for alternative $a$ over $b$ for the $j_{t h}$ criterion.

$$
d_{j}(a, b)=x_{a j}-x_{b j}
$$

Step 3: The preference function for each criterion is selected. According to Equation (14), the preference function can transform the difference between two alternatives into a preference degree that ranges from zero to one. Usually, six types of generalized preference functions can be used: (1) usual criterion, (2) U-shaped criterion, (3) V-shaped criterion, (4) level criterion, (5) V-shaped with indifference criterion, and (6) Gaussian criterion, as shown in Equations (15)-(20). Among them, the V-shaped criterion is more widely used in practice.

$$
\begin{aligned}
& P_{j}(d)=F_{j}\left[d_{j}(a, b)\right] ; \\
& P(d)=\left\{\begin{array}{ll}
1 & d>0 \\
0 & d \leq 0
\end{array} ;\right. \\
& P(d)=\left\{\begin{array}{ll}
1 & d>p \\
0 & d \leq p
\end{array} ;\right. \\
& P(d)=\left\{\begin{array}{cc}
1 & d>p \\
d / p & d \leq p
\end{array} ;\right. \\
& P(d)=\left\{\begin{array}{cc}
1 & d>p \\
0.5 & q<d \leq p \\
0 & d \leq q
\end{array}\right. \\
& P(d)=\left\{\begin{array}{cc}
1 & d>p \\
(d-q) /(p-q) & q<d \leq p ; \\
0 & d \leq q
\end{array}\right. \\
& P(d)=\left\{\begin{array}{cc}
1-e^{\left(-d^{2} / 2 \sigma^{2}\right)} & d>0 \\
0 & d \leq 0
\end{array} .\right.
\end{aligned}
$$


Step 4: The global preference index for all alternatives is determined by Equation (21); then, their positive and negative outranking flows $\phi^{+}\left(d_{i}\right)$ and $\phi^{-}\left(d_{i}\right)$ are calculated by Equations (22) and (23), respectively.

$$
\begin{gathered}
\pi\left(d_{a b}\right)=\sum_{j=1}^{n} P_{j}\left(d_{a b}\right) \omega_{j}, \\
\phi^{+}\left(d_{i}\right)=\frac{1}{m-1} \sum_{k=1}^{m} \pi\left(d_{i k}\right), \\
\phi^{-}\left(d_{i}\right)=\frac{1}{m-1} \sum_{k=1}^{m} \pi\left(d_{i a}\right),
\end{gathered}
$$

where $k=1,2, \cdots, m$, and $k \neq i$.

Step 5: The net outranking flow, which represents the final rank of the alternatives, can be determined by Equation (24), where a greater value is better.

$$
\phi\left(d_{i}\right)=\phi^{+}\left(d_{i}\right)-\phi^{-}\left(d_{i}\right)
$$

\section{Results}

When the dimensions, components, and metrics of mineral security were determined (see Table 1), the pairwise comparisons with respect to the five dimensions and the metrics in each dimension were derived by collecting the opinions of several experts. In this paper, three experts were invited to make the judgment matrices using linguistic terms, and the linguistic judgment matrices are shown in Appendix A (Tables A1-A6). To help understand how to use Fuzzy AHP to determine the weight of each dimension and indicator of mineral security, we took the weight computing for the five dimensions as an example.

The pairwise comparisons for the five dimensions were translated into fuzzy scales by Table 2, and the fuzzy comparison matrix is shown in Table A7 in Appendix A. In order to synthesize the judgments of three experts, an averaged fuzzy judgment matrix was derived from them, as shown in Table A8 in Appendix A. After that, the procedure of fuzzy AHP could be used to determine the weight of the five dimensions of mineral security.

With the averaged fuzzy comparison matrix, the value of fuzzy synthetic extent with respect to the five dimensions can be determined by Equations (2)-(4) as follows:

$$
\begin{aligned}
& S_{1}=(6.3333,8.3333,10.3333) \otimes(1 / 37.1189,1 / 27.4667,1 / 20.6952)=(0.1703,0.3034,0.4993) ; \\
& S_{2}=(3.3778,4.6667,6.6111) \otimes(1 / 37.1189,1 / 27.4667,1 / 20.6952)=(0.0908,0.1699,0.3195) ; \\
& S_{3}=(4.5556,6.1111,8.0000) \otimes(1 / 37.1189,1 / 27.4667,1 / 20.6952)=(0.1225,0.2225,0.3866) ; \\
& S_{4}=(2.9952,3.8556,5.8000) \otimes(1 / 37.1189,1 / 27.4667,1 / 20.6952)=(0.0805,0.1404,0.2803) ; \\
& S_{5}=(3.4333,4.5000,6.4444) \otimes(1 / 37.1189,1 / 27.4667,1 / 20.6952)=(0.0923,0.1638,0.3114) .
\end{aligned}
$$

After that, the degree of possibility of $\widetilde{p}_{i j}=V\left(S_{i} \geq S_{j}\right)$ can be derived according to Equation (5). Let us take the computation of possibility of $S_{2} \geq S_{1}$ as an example. The value of possibility of $S_{2} \geq S_{1}$ can also be rewritten as $\widetilde{p}_{21}=V\left(S_{2} \geq S_{1}\right)=\frac{S_{1}^{L}-S_{2}^{U}}{\left(S_{2}^{M}-S_{2}^{U}\right)-\left(S_{1}^{M}-S_{1}^{L}\right)}=\frac{0.1703-0.3195}{(0.1699-0.3195)-(0.3034-0.1703)}=$ 0.5277. With all degrees of possibility of $S_{i} \geq S_{j}$, the possibility matrix can be determined according to Equation (6), and the results are presented in Table A9 in Appendix A.

After that, the minimum degree of possibility of $V\left(S_{i} \geq S_{1}, S_{2}, \cdots, S_{k}, \cdots, S_{n}\right)$ can be obtained according to Equation (7). 


$$
\begin{aligned}
& V\left(S_{1} \geq S_{k}\right)=\min (1.0000,1.0000,1.0000,1.0000)=1.0000 \\
& V\left(S_{2} \geq S_{k}\right)=\min (0.5277,0.7893,1.0000,1.0000)=0.5277 \\
& V\left(S_{3} \geq S_{k}\right)=\min (0.7277,1.0000,1.0000,1.0000)=0.7277 \\
& V\left(S_{4} \geq S_{k}\right)=\min (0.4028,0.8651,0.6577,0.8890)=0.4028 \\
& V\left(S_{5} \geq S_{k}\right)=\min (0.5027,0.9732,0.7631,1.0000)=0.5027
\end{aligned}
$$

Therefore, the weight vector for the five dimensions can be obtained by Equation (8), and the result is as follows:

$$
W^{\prime}=(1.0000,0.5277,0.7277,0.4028,0.5027)^{T} .
$$

Then, the normalized weight vector can be determined by Equations (9) and (10) as

$$
W=(0.3164,0.1669,0.2302,0.1274,0.1591)^{T} .
$$

With the same procedure, the normalized weight of metrics in each dimension can also be derived. With the weight of the dimensions and indicators of each metric, the global weight of each metric can be obtained, which is the arithmetic product of the metric's weight and the weight of the dimension it belongs to; the results are shown in Table A10 in Appendix A.

With the weight of the metrics determined, we could evaluate the energy security performance of several critical minerals in China. In this study, six minerals (iron, copper, aluminum, lead, zinc, and nickel) were selected as critical minerals because of their broad range of uses in industrial production and daily life. The data with respect to the six minerals were collected for the period of 2001 to 2015, and the data sources are listed in Table 1. In order to facilitate the procedure, Visual PROMETHEE, a type of software specialized for the procedure of PROMETHEE, was used in this study.

Figure 1 present the results of iron's security performance assessment. The values of Phi+ and Phi- represent the positive and negative outranking flows with respect to each year from 2001 to 2015, and the value of Phi is the net outranking flow.

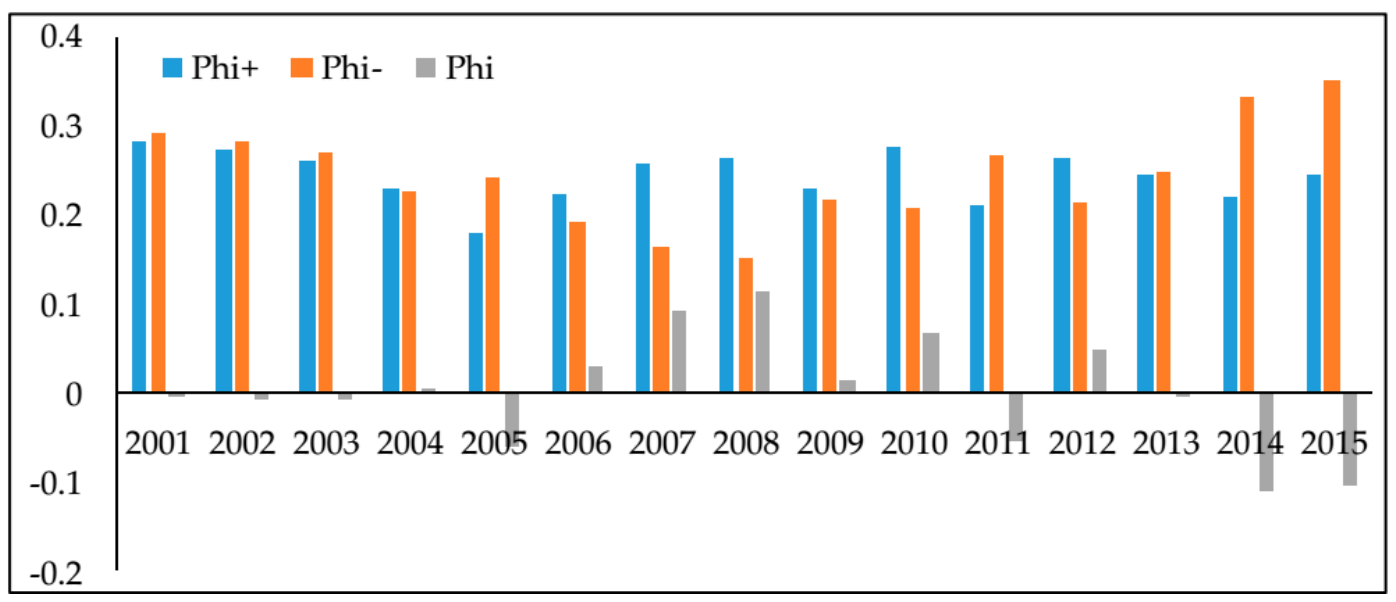

Figure 1. Positive outranking flow (Phi+), negative outranking flow (Phi-), and net outranking flow (Phi) for the iron security assessment.

With a similar approach, we could get the net outranking flows with respect to other critical minerals during the period of 2001-2015, as shown in Figure 2, which indicates the mineral security performance for these minerals.

As we can see from Figure 2, during the period of 2001-2015, the security performance for iron and copper shared a similar evolution, starting with a downturn early on, before experiencing a concussive rise from 2006 to 2008, and finally decreasing gradually and windingly. Overall, the security performance for these two minerals showed a certain degree of decline. For aluminum and 
lead, their security performance presented an uprising trend during this period, and, although some fluctuation was witnessed, it resulted in a historically high level. Zinc also presented an ascension trend; however, this process was full of twists and turns. At the very beginning, it was at a relatively low level; then, it experienced some ups and downs, leading to a relatively high position between 2005 and 2008, followed by falling into a trough from 2009 to 2011, then climbing up to the highest level in 2012 , before keeping a steady tendency with some minor drops. The security performance of another critical metal, nickel, went in the opposite direction. Initially, it experienced a substantial decline from 2001 to 2006, except for a minor rise in 2005. After that, it went through a period of ups and downs. It witnessed an unexpected rise in 2007, and then declined from 2007 to 2009. Another ascent appeared in 2010, before a sudden fall in 2011. Thereafter, it fell into a downturn in the following years.

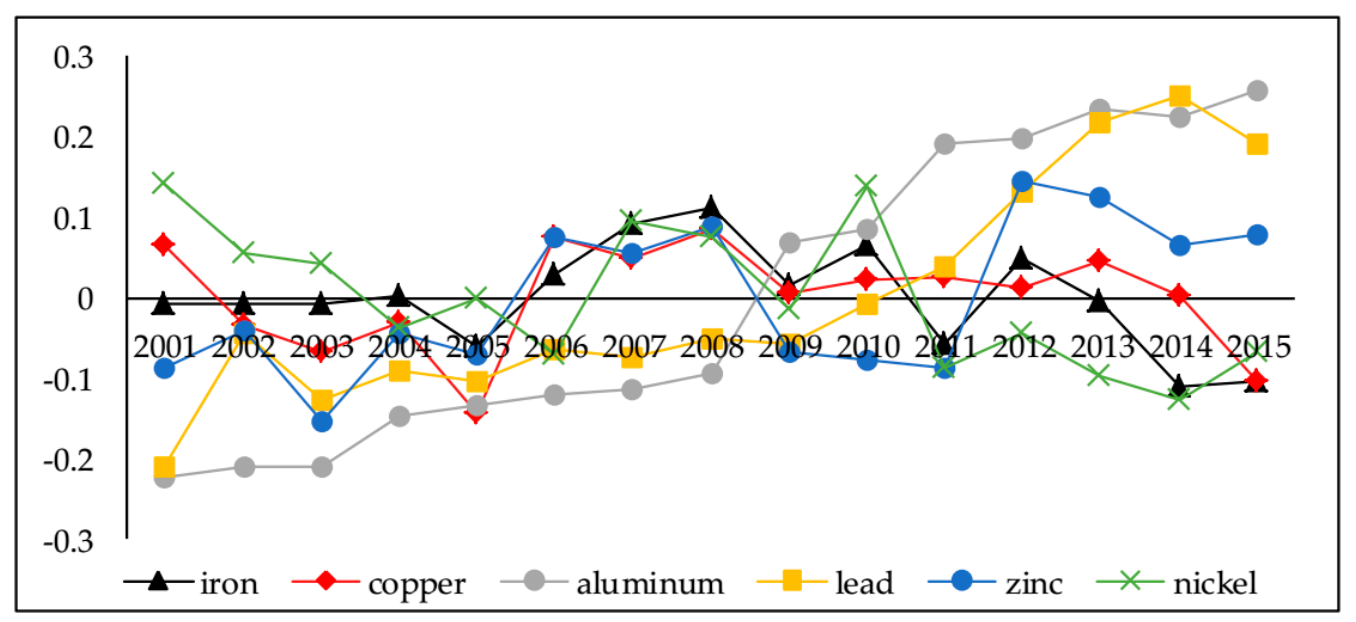

Figure 2. Mineral security performance for six critical minerals during the period of 2001-2015.

In order to better understand the evolution of mineral security in China, a more detailed dimensional analysis was conducted. Figure 3 presents the results of dimensional analyses for the security performance of iron, copper, aluminum, lead, zinc, and nickel, from which we could identify some critical factors that affected China's mineral security during the past 15 years.

The dimension of availability seemed to have a decisive influence on mineral security performance. From Figure 3, we can find that the dimensional performance of availability with respect to iron, copper, zinc, and nickel showed a deteriorating trend, whereas that for aluminum and lead indicated an upward incline, which is consistent with the results of the previous mineral security performance assessment. In fact, the dimension of availability mainly involves the issues of mineral reserves and production. During this period, the basic reserves of iron, copper, and nickel dropped rapidly, while the reserves of zinc showed large fluctuation. On the other hand, a great increase in reserves of aluminum and lead was witnessed. As it approached the end of domestic mineral production, China made great efforts to increase its mineral output to guarantee mineral supply, and encouraged the merging of mining enterprises to improve the production scale. However, since China's demand for minerals grew much faster than its production, it turned to the international mineral market (e.g., Australia, Russia, Canada, Africa, Brazil, and southeast Asia) for supply.

For the dimension of accessibility, it is noticed that the minerals could be classified into two categories. Iron, zinc, and nickel demonstrated a declining trend performance, while copper, aluminum, and lead showed improving momentum, despite some undulations witnessed in the performance of both categories of minerals. To be specific, the dimension of accessibility accesses the reliability of mineral supply from the prospective of the outside market, which is measured by importing sources, mineral prices at the international mineral market, and transport security. Firstly, with respect to the concentration of importing sources, an increasing concentration was witnessed for iron, zinc, and nickel, while a decreasing concentration was found in the security performance of aluminum, lead, 
and zinc, which relate to the dimensional performance of accessibility. Secondly, we saw that the prices for all minerals grew during the past 15 years, among which, the price for aluminum showed less variation than that for other minerals. Thirdly, transport security was measured by pirate attacks around the world. Pirate activities had two active periods during the 15-year period: the duration of 2001 to 2004, and the duration of 2009 to 2011.

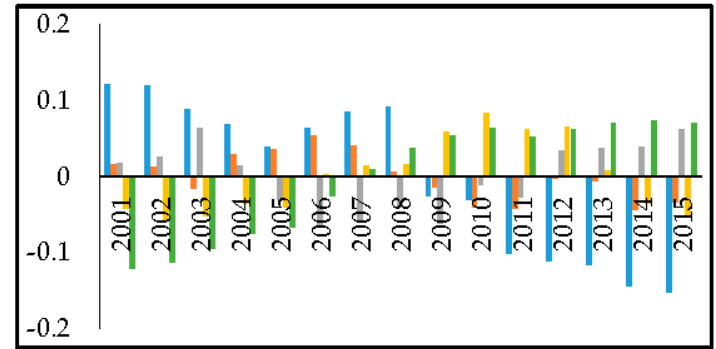

(a)

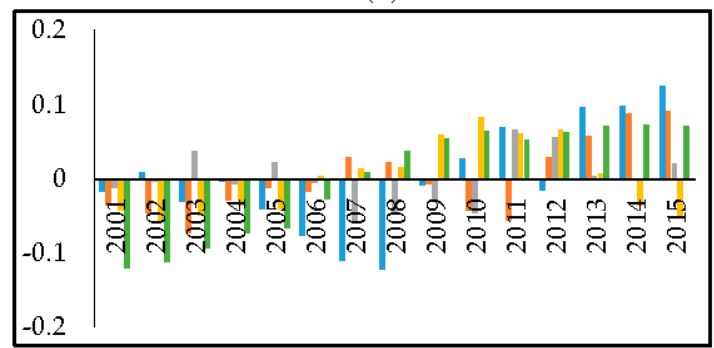

(c)

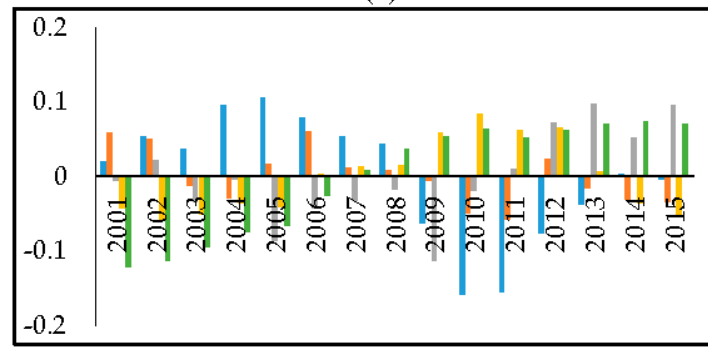

(e)

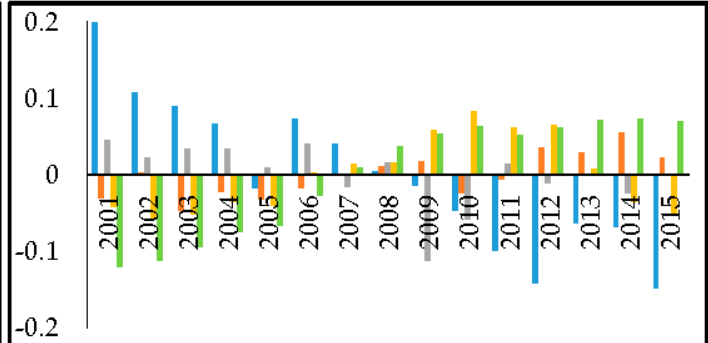

(b)

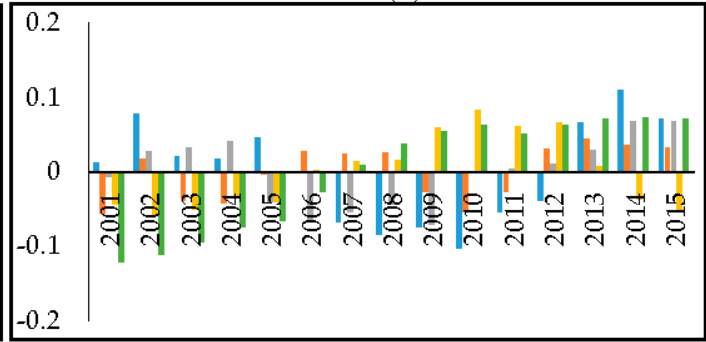

(d)

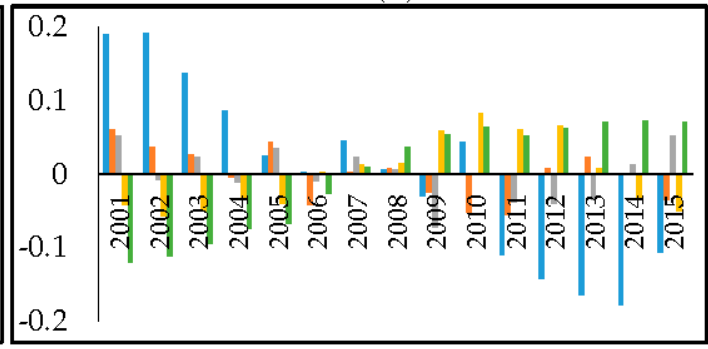

(f)

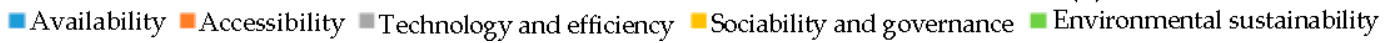

Figure 3. Dimensional security analysis of China's critical minerals: (a) iron; (b) copper; (c) aluminum; (d) lead; (e) zinc; (f) nickel.

The weakest cycle for China's mineral security was the dimension of technology and efficiency. Although great achievements in mining technologies were made, it could not change the fact that China did not have any advantages compared with great mining countries, e.g., Russia, Australia, Canada, and even Brazil, India, and Chile, not to mention the Unites States of America. A few reasons can explain this. First of all, the low grade of ore and the presence of large amounts of associated minerals increased the difficultly of sorting, and reduced the efficiency of mineral utilization. A typical characteristic of China's mineral reserves is richness in low-grade ore, and a lack of high-grade ore, which is very different from that of minerals reserves in other mining countries. Another reason is that the rapid growth of China's demand for minerals gave birth to large numbers of small- and mid-sized mining companies, which urgently pursued rapid profitability, and were not willing to invest in research and development (R\&D). As a consequence, the mining resources were exploited excessively, improperly, and discretely, and the minerals could not be acquired with an economic scale without the introduction and application of advanced technology and equipment.

The dimension of sociability and governance involves three components as mentioned previously: employment, investment and expenditure, and governance efficiency. As a non-emerging industry, less and less people seem to be engaged or interested in this industry; as such, it was witnessed that the 
proportion of mining employees in total social employment declined from nearly $5 \%$ in 2001 to $3 \%$ in 2015, as did the illegal mining activities. However, their wages showed an inverted V-shaped change, which increased continuously from $90 \%$ of the social average to $125 \%$ by 2011 , after which the ratio began decreasing to $96 \%$ in 2015 . The two indicators of investment and expenditure (investment on mining exploration and government expenditure on mining environment restoration and treatment) also demonstrated a similar trend of an inverted V-shape. A possible reason for this could be the macroeconomic economic development in China. The Chinese economy achieved an average economy growth rate of more than $10 \%$ for the first decade of the 21st century, and then slowed down from 2011 onward [53]. Since then, the demand for minerals began decreasing, along with a large amount of excess capacity surfacing in the steel and non-ferrous metal industries [54], and a series of policies aimed at removing excess capacities were implemented [55], which explained the evolution of the dimension of sociability and governance.

The last dimension, environmental sustainability, showed tremendous improvement during the past 15 years. Although China is criticized for serious environmental problems, especially the city fog in northern China, we cannot deny the fact that changes happened. According to data from the National Bureau of Statistics of China, the emissions of most industrial pollutants declined. In fact, the ideology for economic development in China changed since the early 2000s, when the scientific outlook on development was proposed in 2003 by President Hu Jintao [56]. However, the reality is still very pessimistic, since half of the world's mineral consumption was contributed by China [57], which is a great share of China's environmental problems.

\section{Policy Implications}

According to the results of national and dimensional analysis of security performance measurements for China's critical minerals, some valuable policy implications for improving China's mineral security were presented.

Firstly, the data strongly suggest that the dimension of availability makes the most important contribution to mineral security. Mineral resources are considered to be non-renewable, so there exists a paradox between the limited resource supply and the continuous demand for minerals. In order to tackle this contradiction, several solutions are available. The first one is strengthening the efforts in geological exploration and research to increase the availability of resources. The second would be metal recycling and secondary utilization. In fact, recycled metals can be of great potential for supplying critical resources. In recent years, European countries imported large amounts of stainless steel scrap from Russia, while China also imported stainless steel scrap from Japan and South Korea, which reduced the consumption of raw nickel. According to the data from the World Metal Statistics Yearbook, near half of the world's refined copper supply was contributed by recycled copper scrap in 2015. In developed countries, recycled metals took an important position in mineral supply, whereby more than $70 \%$ of refined aluminum consumption in the United States came from recycled scrap in 2015, and that number in Japan and Germany was $43.45 \%$ and $29.5 \%$, respectively.

Secondly, China needs to manage its diversity of mineral importing sources. During the past years, about half of the world's mineral consumption was contributed by China; thus, China has to acquire the necessary raw minerals from the international market. According to the data from the China Mineral Resources Report, the external dependence with respect to iron, copper, and nickel ores exceeded $70 \%$, which is a great threat for national mineral security. Traditionally, Australia and Brazil monopolized $80 \%$ of China's iron ore external supply, while Indonesia and Australia also controlled most of China's aluminum imports. In order to reduce the risks of unexpected supply interruption and inflation of prices, a strategy of diversification is needed. In fact, the Chinese government already took action and tried improving its diversity of importing sources. The Belt and Road Initiative is a strategy that can facilitate the international cooperation between China and the world [58,59], and China already initiated a series of cooperative projects in the energy and mining industry with Kazakhstan, 
as well as other members in central Asia, which is home to rich deposits of copper, gold, uranium, and other minerals [60], and provides additional access for China's mineral supply.

Thirdly, improvements in technology and efficiency are necessary. On the one hand, considering the reality that a large amount of low-grade, associated, or symbiotic ores exist in China, the difficulty and cost of mining and processing activities increased sharply. The introduction of more efficient and advanced equipment can not only help to reduce the cost and improve the efficiency in mineral production, but also increase mineral output. On the other hand, alternative materials need to be developed, introduced, and promoted in commercialized production and application. Composite materials can be used as an alternative to replace steel members in construction and the automobile industry $[61,62]$. For example, engineered thermoplastic materials provide consistent strength and stiffness for metal replacement, while being lighter and stronger than aluminum, alloys, and other metals, and also reducing total cost and weight of parts [63]. Some other alternative materials, such as glass fiber, carbon fiber, and polymers, are also ideal substitute materials for metals, which became an indispensable raw material for industries such as construction, transportation, electronics, electrical, chemical, metallurgy, environmental protection, and national defense [64-66].

In addition, the role of society should be enhanced to improve mineral security. In the traditional prospective, only enterprises, industry associations, and the government took part in mining and related activities, while social individuals were seldom concerned. In fact, individuals can contribute greatly to build a resource-conserving and environmentally friendly society. With the deep integration and rapid development of electronic technology and information technology, people have increasingly convenient and economic access to electric and electronic products. These products would become old-fashioned and then abandoned when more advanced and updated ones are introduced to the market, which brings about large amounts of waste electrical and electronic equipment (WEEE) [67]. Usually, these WEEE contain a variety of metals, which may release pollutants to water or soil. However, if they can be properly recycled, treated, and processed, not only can environmental pollution be avoided, but valuable metals can also be derived [68]. The recovery and treatment of WEEE require the involvement of individuals, who should understand the value of the transformation from waste to resources. As for the role of government policy, we have to say that a degree of fragmentation has existed for a long time, with contradictions often present. At the early stage of Reform and Opening Up, the policy encouraged small- and medium-sized mining activities to increase mineral supply for the rapidly rising economy [69]. However, this policy inclination changed to another direction since stepping into the 21st century, whereby small- and medium-sized mines are no longer promoted. Instead, they were shut down or merged continuously, especially as the policy implemented in late 2015 was going to remove large amounts of overcapacity, mainly in the coal, steel, and non-ferrous industries [70]. The inconsistency of the policy was probably brought by the changes in the macroeconomic situation; however, it still reflects that the government policy was kind of arbitrary, and less forward-looking and predictive.

Lastly, environmental awareness and literacy should be improved within this country. For a few decades, economic development was the top priority of China; hence, minerals and resources were exploited and processed recklessly, leading to serious vegetation damage, soil erosion, and air, water, and soil pollution [71]. During the process of ore milling and washing, heavy-metal pollution could be emitted into water and soil, which is extremely harmful for the growth of animals and plants, and even human health indirectly. However, environmental literacy was ignored intentionally or unintentionally, and how human behavior affects the environment is poorly understood, with people often not realizing that their own actions are causing environmental harm [72]. Although the government tried improving public environmental awareness and literacy in recent years, illegal pollution still exists. What is more, large amounts of tailings are generated from the mining industry, which need land for storage. The metallic element in the tailing impoundment will seep into the earth, and contaminate the soil and underground water. How to deal with large areas of tailing impoundments and land reclamation in mining areas are the most crucial problems in mining industry. 


\section{Conclusions and Discussion}

By relying on the hybrid multiple criteria decision-making (MCDM) methods of fuzzy AHP and PROMETHEE, we evaluated the security of several critical minerals for China during the period of 2001 to 2015, and we can draw some conclusions from the analysis.

Firstly, this study revealed that the traditional concept of mineral security is only limited to the supply security of minerals, which has some obvious deficiencies. A wrong cognition on the dependence of external mineral supplies persisted for a long time. The external market provides additional access for mineral supply, which makes up for the losses caused by insufficient domestic supply. Hence, what affects national mineral security is not external dependence; instead, it is the concentration of importing sources that increases the risks of unexpected mineral supply disruption. In addition, the traditional view of mineral security ignored other noticeable dimensions such as technology and efficiency, society and governance, and environmental sustainability. In fact, our research gave higher weights to the dimensions of availability and accessibility, which indicates their vital roles in national mineral security. However, in the context of sustainable development, other dimensions can also make great contributions to improving mineral security performance from different aspects, which makes mineral security a multidimensional system. Moreover, our research assessed the security performance for several critical minerals of China, and the results indicate that China struggled with its mineral security during the past years, which was at an unfavorable position, and showed great variance.

Meanwhile, a low to moderate level of security was recognized for China's several minerals. To be specific, iron, copper, and nickel were in an unsecure situation for their extremely short domestic supply in China, and showed a downswing. On the other hand, as the preponderant minerals, lead and zinc were at a relatively secure position and uprising; however, they were exhausting their superiority for the huge and rapid-growth economic demand. Aluminum, as a mineral that China seriously depends on for imports, also demonstrated an upward trend due to the successful management of diversity of importing sources. We can conclude that mineral security can be improved through a variety of ways, e.g., diversifying importing sources, exercising control over the overall demand increase, and improving mining processes.

Moreover, we can find that China is facing a huge dilemma in mineral security at the present time. On the one hand, it needs the mineral industry to provide adequate mineral resources to sustain the flourishing Chinese economy; on the other hand, it suffers the serious side effect of environmental disruption and pollution caused by the massive exploitation of mineral resources, which caused great damage to public health. Thus, investment into the R\&D of efficient mining equipment and processes is essential for China to get out of this dilemma. In fact, compared with other mining giants, e.g., Australia, Canada, the United States, and Brazil, China is extremely decentralized in mining production, with small and micro mines scattered across the country, which causes both inefficiency in production and environmental losses.

In this paper, we used the hybrid model of fuzzy AHP and PROMETHEE to evaluate the security performance of China's critical minerals. However, there are still some aspects that can be improved. Firstly, with the dynamic development of technology and society, the context of mineral security is increasingly intricacy and intertwined, and we can try analyzing it from the perspective of complexity science. Secondly, policy-makers usually care more about future trends instead of past experience, so the prediction and forecast of mineral security can be the focus of follow-up studies. Finally, we only discussed the security performance of six critical minerals, namely, iron, copper, aluminum, lead, zinc, and nickel; there are, however, some other minerals, such as rare earth, uranium, tungsten, molybdenum, lithium, and platinum group elements, which are of more strategic significance to the national and economic security, and can be a very interesting topic in this field.

Author Contributions: L.Z. and J.Y. designed the framework of the research; W.B. collected the data; L.Z. and L.M. analyzed and interpreted the data; L.Z. and W.B. prepared a draft of the article; J.R., W.Z., and Y.C. reviewed and edited the draft. 
Funding: This research was funded by the tendering project of Government Decision Making Research in Henan Province (2018B132), the Key Scientific Research Project of Colleges and Universities in Henan Province (19A790020), and the Nanhu Scholars Program for Young Scholars of XYNU.

Acknowledgments: The authors are grateful to editors and anonymous referees for their very valuable comments and suggestions, which significantly helped improve the quality of this paper.

Conflicts of Interest: The authors declare no conflicts of interest.

\section{Appendix A}

Tables A1-A6 show the linguistic judgment matrices with respect to the overall goal of mineral security and the five dimensions.

Table A1. The judgment matrix with respect to the five dimensions of mineral security using linguistic terms.

\begin{tabular}{cccccc}
\hline $\begin{array}{c}\text { Availability } \\
\left(\mathbf{A}_{\mathbf{1}}\right)\end{array}$ & $\begin{array}{c}\text { Accessibility } \\
\left(\mathbf{A}_{\mathbf{2}}\right)\end{array}$ & $\begin{array}{c}\text { Technology and } \\
\text { Efficiency }\left(\mathbf{A}_{\mathbf{3}}\right)\end{array}$ & $\begin{array}{c}\text { Sociability and } \\
\text { Governance }\left(\mathbf{A}_{\mathbf{4}}\right)\end{array}$ & $\begin{array}{c}\text { Environmental } \\
\text { Sustainability }\left(\mathbf{A}_{5}\right)\end{array}$ \\
\hline $\mathrm{A}_{1}$ & $\mathrm{E}$ & $\mathrm{M}$ & $\mathrm{W}$ & $\mathrm{V}$ & $\mathrm{F}$ \\
$\mathrm{A}_{2}$ & $\mathrm{RM}$ & $\mathrm{E}$ & $\mathrm{RW}$ & $\mathrm{W}$ & $\mathrm{M}$ \\
$\mathrm{A}_{3}$ & $\mathrm{RW}$ & $\mathrm{W}$ & $\mathrm{E}$ & $\mathrm{F}$ & $\mathrm{W}$ \\
$\mathrm{A}_{4}$ & $\mathrm{RV}$ & $\mathrm{RW}$ & $\mathrm{RF}$ & $\mathrm{E}$ & $\mathrm{RM}$ \\
$\mathrm{A}_{5}$ & $\mathrm{RF}$ & $\mathrm{RM}$ & $\mathrm{RW}$ & $\mathrm{M}$ & $\mathrm{E}$ \\
\hline
\end{tabular}

Table A2. The judgment matrix with respect to the dimension of availability $\left(\mathrm{A}_{1}\right)$ using linguistic terms.

\begin{tabular}{ccccccc}
\hline & $\begin{array}{c}\mathbf{I}_{\mathbf{1}} \text { : Reserve to } \\
\text { Production } \\
\text { Ratio }\end{array}$ & $\begin{array}{c}\mathbf{I}_{2}: \text { Per Capita } \\
\text { Mineral } \\
\text { Reserves }\end{array}$ & $\begin{array}{c}\mathbf{I}_{3} \text { : Ratio of Domestic } \\
\text { Mineral Reserves to } \\
\text { World Total }\end{array}$ & $\begin{array}{c}\mathbf{I}_{4} \text { : Self- } \\
\text { Sufficiency }\end{array}$ & $\begin{array}{c}\mathbf{I}_{5} \text { : Production } \\
\text { Centralization }\end{array}$ & $\begin{array}{c}\mathbf{I}_{6}: \text { Ratio of Domestic } \\
\text { Mineral Production } \\
\text { to World Total }\end{array}$ \\
\hline $\mathrm{I}_{1}$ & $\mathrm{E}$ & $\mathrm{M}$ & $\mathrm{W}$ & $\mathrm{W}$ & $\mathrm{A}$ & $\mathrm{M}$ \\
$\mathrm{I}_{2}$ & $\mathrm{RM}$ & $\mathrm{E}$ & $\mathrm{RM}$ & $\mathrm{RW}$ & $\mathrm{W}$ & $\mathrm{M}$ \\
$\mathrm{I}_{3}$ & $\mathrm{RW}$ & $\mathrm{M}$ & $\mathrm{E}$ & $\mathrm{W}$ & $\mathrm{V}$ & $\mathrm{F}$ \\
$\mathrm{I}_{4}$ & $\mathrm{RW}$ & $\mathrm{W}$ & $\mathrm{RW}$ & $\mathrm{RF}$ & $\mathrm{E}$ & $\mathrm{W}$ \\
$\mathrm{I}_{5}$ & $\mathrm{RA}$ & $\mathrm{RM}$ & $\mathrm{RV}$ & $\mathrm{RF}$ & $\mathrm{RW}$ & $\mathrm{E}$ \\
$\mathrm{I}_{6}$ & $\mathrm{RV}$ & $\mathrm{RM}$ & $\mathrm{RF}$ & & & $\mathrm{F}$ \\
\hline
\end{tabular}

Table A3. The judgment matrix with respect to the dimension of accessibility $\left(\mathrm{A}_{2}\right)$ using linguistic terms.

\begin{tabular}{cccc}
\hline & $\begin{array}{c}\mathbf{I}_{7} \text { : Concentration of } \\
\text { Importing Sources }\end{array}$ & $\begin{array}{c}\text { I }_{8} \text { : Mineral Price in } \\
\text { International Market }\end{array}$ & $\begin{array}{c}\text { I9: Safety of Transport } \\
\text { Routes }\end{array}$ \\
\hline $\mathrm{I}_{7}$ & $\mathrm{E}$ & $\mathrm{F}$ & $\mathrm{W}$ \\
$\mathrm{I}_{8}$ & $\mathrm{RF}$ & $\mathrm{E}$ & $\mathrm{RM}$ \\
$\mathrm{I}_{9}$ & $\mathrm{RW}$ & $\mathrm{M}$ & $\mathrm{E}$ \\
\hline
\end{tabular}

Table A4. The judgment matrix with respect to the dimension of technology and efficiency $\left(\mathrm{A}_{3}\right)$ using linguistic terms.

\begin{tabular}{ccccc}
\hline $\begin{array}{c}\mathbf{I}_{\mathbf{1 0}}: \text { Mining Technology } \\
\text { Innovations }\end{array}$ & $\begin{array}{c}\mathbf{I}_{\mathbf{1 1}} \text { : Newly } \\
\text { Discovered Reserves }\end{array}$ & $\begin{array}{c}\mathbf{I}_{\mathbf{1 2}} \text { : Mineral } \\
\text { Intensity }\end{array}$ & $\begin{array}{c}\mathbf{I}_{\mathbf{1 3}} \text { : Comprehensive } \\
\text { Utilization of Minerals }\end{array}$ \\
\hline $\mathrm{I}_{10}$ & $\mathrm{E}$ & $\mathrm{M}$ & $\mathrm{RW}$ & $\mathrm{M}$ \\
$\mathrm{I}_{11}$ & $\mathrm{RM}$ & $\mathrm{E}$ & $\mathrm{RV}$ & $\mathrm{RW}$ \\
$\mathrm{I}_{12}$ & $\mathrm{~W}$ & $\mathrm{~V}$ & $\mathrm{E}$ & $\mathrm{M}$ \\
$\mathrm{I}_{13}$ & $\mathrm{RM}$ & $\mathrm{W}$ & $\mathrm{RM}$ & $\mathrm{E}$ \\
\hline
\end{tabular}


Table A5. The judgment matrix with respect to the dimension of sociability and governance $\left(\mathrm{A}_{4}\right)$ using linguistic terms.

\begin{tabular}{cccccc}
\hline & $\begin{array}{c}\mathbf{I}_{\mathbf{1 4}} \text { : Proportion of } \\
\text { Mining Industry in } \\
\text { Total Employment }\end{array}$ & $\begin{array}{c}\mathrm{I}_{\mathbf{1 5}} \text { : Wage Level } \\
\text { of Mining } \\
\text { Industry }\end{array}$ & $\begin{array}{c}\mathbf{I}_{\mathbf{1 6}} \text { : Investment } \\
\text { on Exploration }\end{array}$ & $\begin{array}{c}\mathbf{I}_{\mathbf{1 7}} \text { : Investment on } \\
\text { Mining Environment } \\
\text { Restoration }\end{array}$ & $\begin{array}{c}\mathrm{I}_{\mathbf{1 8}} \text { : Cases of } \\
\text { Illegal Mining } \\
\text { Activities }\end{array}$ \\
\hline $\mathrm{I}_{14}$ & $\mathrm{E}$ & $\mathrm{RW}$ & $\mathrm{RV}$ & $\mathrm{RA}$ & $\mathrm{RW}$ \\
$\mathrm{I}_{15}$ & $\mathrm{~W}$ & $\mathrm{E}$ & $\mathrm{RM}$ & $\mathrm{RV}$ & $\mathrm{M}$ \\
$\mathrm{I}_{16}$ & $\mathrm{~V}$ & $\mathrm{M}$ & $\mathrm{E}$ & $\mathrm{E}$ & $\mathrm{V}$ \\
$\mathrm{I}_{17}$ & $\mathrm{~A}$ & $\mathrm{~V}$ & $\mathrm{E}$ & $\mathrm{E}$ & $\mathrm{V}$ \\
$\mathrm{I}_{18}$ & $\mathrm{~W}$ & $\mathrm{RM}$ & $\mathrm{RV}$ & $\mathrm{RV}$ & $\mathrm{E}$ \\
\hline
\end{tabular}

Table A6. The judgment matrix with respect to the dimension of environmental sustainability $\left(\mathrm{A}_{5}\right)$ using linguistic terms.

\begin{tabular}{|c|c|c|c|c|c|c|c|c|}
\hline & $\begin{array}{c}\text { I }_{19} \text { : } \\
\text { Intensity of } \\
\text { Industrial } \\
\text { Solid Waste } \\
\text { Emissions }\end{array}$ & $\begin{array}{c}\mathbf{I}_{\mathbf{2 0}} \text { : Ratio of } \\
\text { Industrial } \\
\text { Solid Waste } \\
\text { Utilized }\end{array}$ & $\begin{array}{c}\mathbf{I}_{21}: \\
\text { Intensity of } \\
\text { Industrial } \\
\text { Waste Water } \\
\text { Emissions }\end{array}$ & $\begin{array}{c}\mathrm{I}_{22}: \\
\text { Intensity of } \\
\text { Industrial } \\
\text { COD } \\
\text { Emissions }\end{array}$ & $\begin{array}{c}\mathrm{I}_{23}: \\
\text { Intensity of } \\
\text { Industrial } \\
\mathrm{NH}_{3}-\mathrm{N} \\
\text { Emissions }\end{array}$ & $\begin{array}{c}\mathrm{I}_{24}: \\
\text { Intensity of } \\
\text { Industrial } \\
\mathrm{SO}_{2} \\
\text { Emissions }\end{array}$ & $\begin{array}{c}\mathbf{I}_{25}: \\
\text { Intensity of } \\
\text { Industrial } \\
\text { Soot and } \\
\text { Dust } \\
\text { Emissions }\end{array}$ & $\begin{array}{c}\mathbf{I}_{26}: \\
\text { Intensity } \\
\text { of NOx } \\
\text { Emissions }\end{array}$ \\
\hline $\mathrm{I}_{19}$ & E & A & E & $\mathrm{F}$ & $\mathrm{F}$ & $\mathrm{M}$ & $\mathrm{W}$ & $\mathrm{F}$ \\
\hline $\mathrm{I}_{20}$ & RA & E & RV & $\mathrm{RM}$ & $\mathrm{RM}$ & $\mathrm{RF}$ & RV & $\mathrm{RM}$ \\
\hline $\mathrm{I}_{21}$ & $\mathrm{E}$ & V & $\mathrm{E}$ & $\mathrm{F}$ & $\mathrm{M}$ & $\mathrm{M}$ & W & $\mathrm{M}$ \\
\hline $\mathrm{I}_{22}$ & $\mathrm{RF}$ & $\mathrm{M}$ & $\mathrm{RF}$ & $\mathrm{E}$ & W & RW & $\mathrm{RM}$ & W \\
\hline $\mathrm{I}_{23}$ & $\mathrm{RF}$ & M & $\mathrm{RM}$ & RW & $\mathrm{E}$ & $\mathrm{RM}$ & $\mathrm{RM}$ & $\mathrm{E}$ \\
\hline $\mathrm{I}_{24}$ & $\mathrm{RM}$ & $\mathrm{F}$ & $\mathrm{RM}$ & W & $\mathrm{M}$ & E & RW & W \\
\hline $\mathrm{I}_{25}$ & RW & $\mathrm{V}$ & RW & $\mathrm{M}$ & M & $\mathrm{W}$ & $\mathrm{E}$ & W \\
\hline $\mathrm{I}_{26}$ & $\mathrm{RF}$ & M & $\mathrm{RM}$ & RW & E & RW & RW & $\mathrm{E}$ \\
\hline
\end{tabular}

Tables A7-A10 display the results of fuzzy AHP.

Table A7. The fuzzy comparison matrix with respect to the five dimensions of three experts.

\begin{tabular}{|c|c|c|c|c|c|}
\hline & $\begin{array}{c}\text { Availability } \\
\left(\mathrm{A}_{1}\right)\end{array}$ & $\begin{array}{c}\text { Accessibility } \\
\left(\mathbf{A}_{2}\right)\end{array}$ & $\begin{array}{l}\text { Technology and } \\
\text { Efficiency }\left(\mathrm{A}_{3}\right)\end{array}$ & $\begin{array}{c}\text { Sociability and } \\
\text { Governance }\left(\mathrm{A}_{4}\right)\end{array}$ & $\begin{array}{c}\text { Environmental } \\
\text { Sustainability }\left(\mathrm{A}_{5}\right)\end{array}$ \\
\hline \multirow{4}{*}{$\mathrm{A}_{1}$} & & $(1,3 / 2,2)$ & $(1 / 2,1,3 / 2)$ & $(2,5 / 2,3)$ & $(3 / 2,2,5 / 2)$ \\
\hline & $(1,1,1)$ & $(1,3 / 2,2)$ & $(1,3 / 2,2)$ & $(3 / 2,2,5 / 2)$ & $(1,3 / 2,2)$ \\
\hline & & $(3 / 2,2,5 / 2)$ & $(1,3 / 2,2)$ & $(5 / 2,3,7 / 2)$ & $(3 / 2,2,5 / 2)$ \\
\hline & $(1 / 2,2 / 3,1)$ & & $(2 / 3,1,2)$ & $(1 / 2,1,3 / 2)$ & $(1,3 / 2,2)$ \\
\hline \multirow[t]{3}{*}{$\mathrm{A}_{2}$} & $(1 / 2,2 / 3,1)$ & $(1,1,1)$ & $(2 / 5,1 / 2,2 / 3)$ & $(2 / 3,1,2)$ & $(1 / 2,1,3 / 2)$ \\
\hline & $(2 / 5,1 / 2,2 / 3)$ & & $(1 / 2,2 / 3,1)$ & $(1,3 / 2,2)$ & $(1 / 2,1,3 / 2)$ \\
\hline & $(2 / 3,1,2)$ & $(1 / 2,1,3 / 2)$ & & $(3 / 2,2,5 / 2)$ & $(1 / 2,1,3 / 2)$ \\
\hline \multirow[t]{3}{*}{$\mathrm{A}_{3}$} & $(1 / 2,2 / 3,1)$ & $(3 / 2,2,5 / 2)$ & $(1,1,1)$ & $(1 / 2,1,3 / 2)$ & $(1,1,1)$ \\
\hline & $(1 / 2,2 / 3,1)$ & $(1,3 / 2,2)$ & & $(3 / 2,2,5 / 2)$ & $(1,3 / 2,2)$ \\
\hline & $(1 / 3,2 / 5,1 / 2)$ & $(2 / 3,1,2)$ & $(2 / 5,1 / 2,2 / 3)$ & & $(1 / 2,2 / 3,1)$ \\
\hline \multirow[t]{3}{*}{$\mathrm{A}_{4}$} & $(2 / 5,1 / 2,2 / 3)$ & $(1 / 2,1,3 / 2)$ & $(2 / 3,1,2)$ & $(1,1,1)$ & $(2 / 3,1,2)$ \\
\hline & $(2 / 7,1 / 3,2 / 5)$ & $(1 / 2,2 / 3,1)$ & $(2 / 5,1 / 2,2 / 3)$ & & $(2 / 3,1,2)$ \\
\hline & $(2 / 5,1 / 2,2 / 3)$ & $(1 / 2,2 / 3,1)$ & $(2 / 3,1,2)$ & $(1,3 / 2,2)$ & \\
\hline \multirow[t]{2}{*}{$\mathrm{A}_{5}$} & $(1 / 2,2 / 3,1)$ & $(2 / 3,1,2)$ & $(1,1,1)$ & $(1 / 2,1,3 / 2)$ & $(1,1,1)$ \\
\hline & $(2 / 5,1 / 2,2 / 3)$ & $(2 / 3,1,2)$ & $(1 / 2,2 / 3,1)$ & $(1 / 2,1,3 / 2)$ & \\
\hline
\end{tabular}

Table A8. The averaged fuzzy comparison matrix with respect to the five dimensions.

\begin{tabular}{cccccc}
\hline & $\mathbf{A}_{\mathbf{1}}$ & $\mathbf{A}_{\mathbf{2}}$ & $\mathbf{A}_{\mathbf{3}}$ & $\mathbf{A}_{\mathbf{4}}$ & $\mathbf{A}_{\mathbf{5}}$ \\
\hline $\mathrm{A}_{1}$ & $(1.000,1.000,1.000)$ & $(1.167,1.667,2.167)$ & $(0.833,1.333,1.833)$ & $(2.000,2.500,3.000)$ & $(1.333,1.833,2.333)$ \\
$\mathrm{A}_{2}$ & $(0.467,0.611,0.889)$ & $(1.000,1.000,1.000)$ & $(0.522,0.722,1.222)$ & $(0.722,1.167,1.833)$ & $(0.667,1.167,1.667)$, \\
$\mathrm{A}_{3}$ & $(0.556,0.778,1.333)$ & $(1.000,1.500,2.000)$ & $(1.000,1.000,1.000)$ & $(1.167,1.67,2.167)$ & $(0.833,1.167,1.500)$ \\
$\mathrm{A}_{4}$ & $(0.340,0.411,0.522)$ & $(0.556,0.889,1.500)$ & $(0.489,0.667,1.111)$ & $(1.000,1.000,1.000)$ & $(0.611,0.889,1.667)$ \\
$\mathrm{A}_{5}$ & $(0.433,0.556,0.778)$ & $(0.611,0.889,1.667)$ & $(0.722,0.889,1.333)$ & $(0.667,1.167,1.667)$ & $(1.000,1.000,1.000)$ \\
\hline
\end{tabular}


Table A9. The degree of possibilities of $S_{i} \geq S_{j}$.

\begin{tabular}{cccccc}
\hline & $S_{1}$ & $S_{2}$ & $S_{3}$ & $S_{4}$ & $S_{5}$ \\
\hline$S_{1}$ & - & 1.0000 & 1.0000 & 1.0000 & 1.0000 \\
$S_{2}$ & 0.5277 & - & 0.7893 & 1.0000 & 1.0000 \\
$S_{3}$ & 0.7277 & 1.0000 & - & 1.0000 & 1.0000 \\
$S_{4}$ & 0.4028 & 0.8651 & 0.6577 & - & 0.8890 \\
$S_{5}$ & 0.5027 & 0.9732 & 0.7631 & 1.0000 & - \\
\hline
\end{tabular}

Table A10. The global and local weights of all the dimensions and metrics.

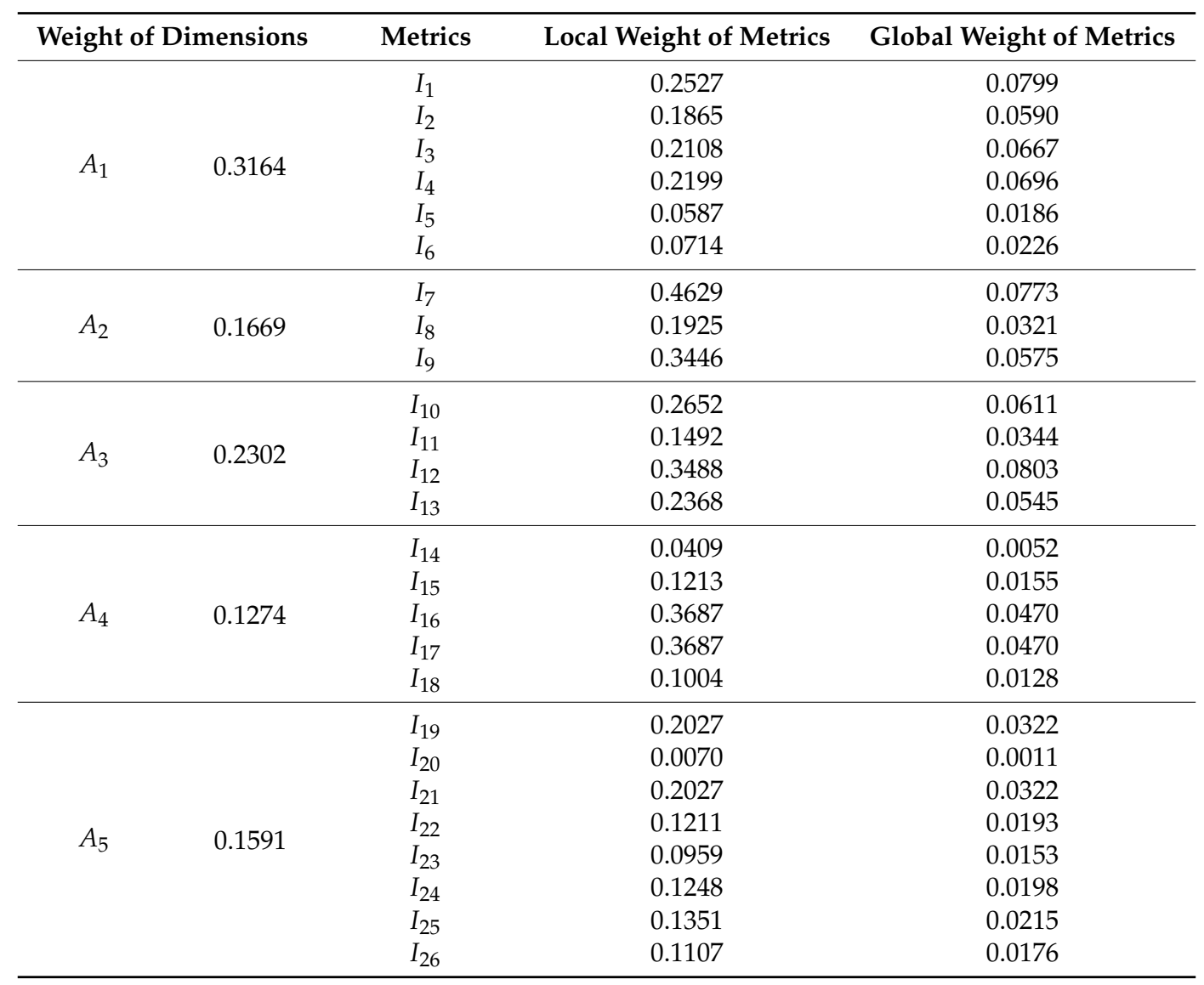

\section{References}

1. Tse, P.K. The mineral industry of China. In US Geological Survey Minerals Yearbook; United States Geological Survey: Reston, VA, USA, 2010.

2. Singh, M.A.; Nabar, M.M.; N’Diaye, M.P.M. China's Economy in Transition: From External to Internal Rebalancing; International Monetary Fund: Washington, DC, USA, 2013.

3. United States Geological Survey. Mineral Commodity Summary. Available online: https://minerals.usgs. gov/minerals/pubs/mcs/2017/mcs2017.pdf (accessed on 27 March 2017).

4. Who Holds the Lifeblood of China? Whose Throat Does China Hold? 2017. Available online: http: / / futures.jrj.com.cn/2017/04/24131622371528.shtml (accessed on 31 July 2018). (In Chinese)

5. Editorial Department of China Mining Yearbook. China Mining Yearbook 2013; Seismological Press: Beijing, China, 2014. (In Chinese)

6. Chopin, E.I.B.; Alloway, B.J. Distribution and mobility of trace elements in soils and vegetation around the mining and smelting areas of Tharsis, Riotinto and Huelva, Iberian Pyrite Belt, SW Spain. Water Air Soil Pollut. 2007, 182, 245-261. [CrossRef] 
7. Kim, S.; Kwon, H.J.; Cheong, H.K.; Choi, K.; Jang, J.Y.; Jeong, W.C.; Kim, D.S.; Yu, S.; Kim, W.Y.; Lee, K.Y.; et al. Investigation on health effects of an abandoned metal mine. J. Korean Med. Sci. 2008, 23, 452-458. [CrossRef] [PubMed]

8. Pusapukdepob, J.; Sawangwong, P.; Pulket, C.; Satraphat, D.; Saowakontha, S.; Panutrakul, S. Health risk assessment of villagers who live near a lead mining area: A case study of Klity village, Kanchanaburi Province, Thailand. Southeast Asian J. Trop. Med. Public Health 2009, 38, 168-177.

9. Zhang, X.; Yang, L.; Li, Y.; Li, H.; Wang, W.; Ye, B. Impacts of lead/zinc mining and smelting on the environment and human health in China. Environ. Monit. Assess. 2012, 184, 2261-2273. [CrossRef] [PubMed]

10. He, B.J.; Zhao, D.X.; Zhu, J.; Darko, A.; Gou, Z.H. Promoting and implementing urban sustainability in China: An integration of sustainable initiatives at different urban scales. Habitat Int. 2018. [CrossRef]

11. He, B.; Zhu, J. Constructing community gardens? Residents' attitude and behaviour towards edible landscapes in emerging urban communities of China. Urban For. Urban Green. 2018, 34, 154-165. [CrossRef]

12. Prior, T.; Giurco, D.; Mudd, G.; Mason, L.; Behrisch, J. Resource depletion, peak minerals and the implications for sustainable resource management. Glob. Environ. Change 2012, 22, 577-587. [CrossRef]

13. Kesler, S.E.; Simon, A.C. Mineral Resources, Economics and the Environment; Cambridge University Press: Cambridge, UK, 2015.

14. Moran, C.J.; Lodhia, S.; Kunz, N.C.; Huisingh, D. Sustainability in mining, minerals and energy: New processes, pathways and human interactions for a cautiously optimistic future. J. Clean. Prod. 2014, 84, 1-15. [CrossRef]

15. Yu, J.; Yao, S.; Chen, R.; Zhu, K.; Yu, L. A quantitative integrated evaluation of sustainable development of mineral resources of a mining city: A case study of Huangshi, Eastern China. Resour. Policy 2005, 30, 7-19. [CrossRef]

16. Hatayama, H.; Tahara, K. Evaluating the sufficiency of Japan's mineral resource entitlements for supply risk mitigation. Resour. Policy 2015, 44, 72-80. [CrossRef]

17. Chen, R.H.; Lin, Y.; Tseng, M.L. Multicriteria analysis of sustainable development indicators in the construction minerals industry in China. Resour. Policy 2015, 46, 123-133. [CrossRef]

18. Ray, G.F. Mineral reserves: Projected lifetimes and security of supply. Resour. Policy 1984, 10, 75-80. [CrossRef]

19. Anderson, D.L. Implications of the Canada-USA Free Trade Agreement for the Canadian minerals industry. Resour. Policy 1988, 14, 121-134. [CrossRef]

20. Harker, R.I.; Lutz, T.M. Securities of mineral supplies. Resour. Policy 1990, 16, 115-127. [CrossRef]

21. Humprheys, D. Whatever happened to security of supply? Minerals policy in the post-Cold War world. Resour. Policy 1995, 21, 91-97. [CrossRef]

22. Pereira, J.J. Mineral security through landuse planning-case study of rock aggregates in Eastern Selangor. Bull. Geol. Soc. Malays. 2007, 53, 89-93.

23. Lusty, P.A.J.; Gunn, A.G. Challenges to global mineral resource security and options for future supply. Geol. Soc. Lond. Spec. Publ. 2015, 393, 265-276. [CrossRef]

24. Hilson, G.; Basu, A.J. Devising indicators of sustainable development for the mining and minerals industry: An analysis of critical background issues. Int. J. Sust. Dev. World 2003, 10, 319-331. [CrossRef]

25. Petrie, J.; Cohen, B.; Stewart, M. Decision support frameworks and metrics for sustainable development of minerals and metals. Clean Technol. Environ. 2007, 9, 133-145. [CrossRef]

26. Azapagic, A. Developing a framework for sustainable development indicators for the mining and minerals industry. J. Clean. Prod. 2004, 12, 639-662. [CrossRef]

27. Lehtonen, M. The environmental-social interface of sustainable development: Capabilities, social capital, institutions. Ecol. Econ. 2004, 49, 199-214. [CrossRef]

28. Pearce, D.; Barbier, E.; Markandya, A. Sustainable Development: Economics and Environment in the Third World; Routledge: Landon, UK, 2013.

29. McLellan, B.C.; Corder, G.D.; Ali, S.H. Sustainability of rare earths-An overview of the state of knowledge. Minerals 2013, 3, 304-317. [CrossRef]

30. Petterson, M.G. Minerals sustainability, emerging economies, the developing world, and the 'truth' behind the rhetoric. Est. J. Earth Sci. 2008, 57, 57-74. [CrossRef]

31. Worrall, R.; Neil, D.; Brereton, D.; Mulligan, D. Towards a sustainability criteria and indicators framework for legacy mine land. J. Clean. Prod. 2009, 17, 1426-1434. [CrossRef] 
32. Cooper, C.; Giurco, D. The Mineral Resources Landscape-An Expanded Conceptualisation of Minerals Sustainability; Australasian Institute of Mining \& Metallurgy: Carlton, Australia, 2009.

33. Giurco, D.; Cooper, C. Mining and sustainability: Asking the right questions. Miner. Eng. 2012, $29,3-12$. [CrossRef]

34. Sovacool, B.K.; Mukherjee, I. Conceptualizing and measuring energy security: A synthesized approach. Energy 2011, 36, 5343-5355. [CrossRef]

35. Liu, G. Development of a general sustainability indicator for renewable energy systems: A review. Renew. Sustain. Energy Rev. 2014, 31, 611-621. [CrossRef]

36. Bambawale, M.J.; Sovacool, B.K. China's energy security: The perspective of energy users. Appl. Energy 2011, 88, 1949-1956. [CrossRef]

37. Von Hippel, D.; Suzuki, T.; Williams, J.H.; Savage, T.; Hayes, P. Energy security and sustainability in Northeast Asia. Energy Policy 2011, 39, 6719-6730. [CrossRef]

38. Ren, J.; Sovacool, B.K. Quantifying, measuring, and strategizing energy security: Determining the most meaningful dimensions and metrics. Energy 2014, 76, 838-849. [CrossRef]

39. Asdrubali, F.; Baldinelli, G.; D'Alessandro, F.; Scrucca, F. Life cycle assessment of electricity production from renewable energies: Review and results harmonization. Renew. Sustain. Energy Rev. 2015, 42, 1113-1122. [CrossRef]

40. Zhang, L.; Yu, J.; Sovacool, B.K.; Ren, J. Measuring energy security performance within China: Toward an inter-provincial prospective. Energy 2017, 125, 825-836. [CrossRef]

41. Shields, D.J.; Blengini, G.A.; Solar, S.V. Integrating life cycle assessment and other tools for ex ante integrated sustainability assessment in the minerals industry. Am. J. Appl. Sci. 2011, 8, 1214-1227. [CrossRef]

42. Govindan, K. Application of multi-criteria decision making/operations research techniques for sustainable management in mining and minerals. Resour. Policy 2015, 46, 1-5. [CrossRef]

43. Kabir, G.; Sumi, R.S. Power substation location selection using fuzzy analytic hierarchy process and PROMETHEE: A case study from Bangladesh. Energy 2014, 72, 717-730. [CrossRef]

44. Chang, D.Y. Applications of the extent analysis method on fuzzy AHP. Eur. J. Oper. Res. 1996, 95, 649-655. [CrossRef]

45. Zhou, M.; Liu, X.B.; Yang, J.B. Evidential reasoning-based nonlinear programming model for MCDA under fuzzy weights and utilities. Int. J. Intell. Syst. 2010, 25, 31-58. [CrossRef]

46. Leung, L.C.; Cao, D. On consistency and ranking of alternatives in fuzzy AHP. Eur. J. Oper. Res. 2000, 124, 102-113. [CrossRef]

47. Kilincci, O.; Onal, S.A. Fuzzy AHP approach for supplier selection in a washing machine company. Expert Syst. Appl. 2011, 38, 9656-9664. [CrossRef]

48. Razmi, J.; Sangari, M.S. A hybrid multi-criteria decision making model for ERP system selection. In Proceedings of the 4th International Conference on Information and Automation for Sustainability, Colombo, Sri Lanka, 12-14 December 2008; pp. 489-495.

49. Liu, P.; Jin, F. Methods for aggregating intuitionistic uncertain linguistic variables and their application to group decision making. Inf. Sci. 2012, 205, 58-71. [CrossRef]

50. Brans, J.P. Lingenierie de la decision. Elaboration dinstrumentsdaide a la decision. Methode PROMETHEE. In Laide a la Decision: Nature, Instrument Set Perspectives Davenir; Nadeau, R., Landry, M., Eds.; Presses de Universite Laval: Quebec, QC, Canada, 1982; pp. 183-214.

51. Brans, J.P.; Vincke, P.h.; Mareschal, B. How to select and how to rank projects: The PROMETHEE method. Eur. J. Oper. Res. 1986, 24, 228-238. [CrossRef]

52. Ren, J.; Lützen, M. Fuzzy multi-criteria decision-making method for technology selection for emissions reduction from shipping under uncertainties. Transp. Res. D Transp. Environ. 2015, 40, 43-60. [CrossRef]

53. World Bank. The World Bank in China. Available online: http://www.worldbank.org/en/country/china/ overview\#1 (accessed on 27 July 2018).

54. Nozomu, K. Where Is the Excess Capacity in the World Iron and Steel Industry?-A Focus on East Asia and China. Available online: https://www.rieti.go.jp/jp/publications/dp/17e026.pdf (accessed on 27 July 2018).

55. Lu, Z. China's Excess Capacity in Steel: A Fresh Look. Peterson Institute for International Economics. Available online: https:/ / piie.com/blogs/china-economic-watch/chinas-excess-capacity-steel-fresh-look (accessed on 27 July 2018). 
56. The Proposition of the Scientific Outlook on Development. Available online: http:/ /www.hprc.org.cn/gsgl/ dsnb/zdsj/201001/t20100109_40258.html (accessed on 27 July 2018).

57. Gulley, A.L.; Nassar, N.T.; Xun, S. China, the United States, and competition for resources that enable emerging technologies. Proc. Natl. Acad. Sci. USA 2018, 115, 4111-4115. [CrossRef] [PubMed]

58. Tang, J.R.; Zhang, T.; Zhou, P.; Zheng, R.R. An analysis of mineral resources distribution and investment climate in the "One Belt, One Road" countries. Geol. Bull. China 2015, 34, 1918-1928.

59. Farooki, M. China's Mineral Sector and the Belt \& Road Initiative. Available online: http://stradeproject.eu/ fileadmin/user_upload/pdf/STRADE_PB_02-2018_One_Belt_One_Road.pdf (accessed on 30 July 2018).

60. Fitch Solutions. One Belt One Road: Central Asia As Largest Mining Beneficiary. Available online: https: / /www.fitchsolutions.com/ corporates / metals-mining/one-belt-one-road-central-asia-largestmining-beneficiary-10-07-2018 (accessed on 30 July 2018).

61. Mangino, E.; Carruthers, J.; Pitarresi, G. The future use of structural composite materials in the automotive industry. Int. J. Veh. Des. 2007, 44, 211-232. [CrossRef]

62. Ramirez-Vazquez, I.; Hernández-Corona, R.; Salgado-Talavera, J.E. Composite Materials as an Alternative to Replace Steel Members on Lattice Power Transmission Towers. J. Mater. Civ. Eng. 2015, 28, 04015151. [CrossRef]

63. DuPont. Innovative Ideas for Metal Replacement. Available online: http://www.dupont.co.uk/productsand-services / plastics-polymers-resins/articles/innovative-ideas-for-metal-replacement.html (accessed on 30 July 2018).

64. Jaroslaw, B.; Barbara, S.; Patryk, J. The comparison of low-velocity impact resistance of aluminum/carbon and glass fiber metal laminates. Polym. Compos. 2016, 37, 1056-1063. [CrossRef]

65. Gibson, R. Using Polymers as an Alternative to Metals. Available online: http://www.dieselduck.info/ library/01\%20articles/polymers.htm (accessed on 30 July 2018).

66. Barker, C. The Feasibility of Fiber Reinforced Polymers as an Alternative to Steel in Reinforced Concrete. Available online: http://digitool.library.mcgill.ca/webclient/StreamGate?folder_id=0\&dvs= 1532919621675 183 (accessed on 30 July 2018).

67. Yang, J.; Lu, B.; Xu, C. WEEE flow and mitigating measures in China. Waste Manag. 2008, 28, $1589-1597$. [CrossRef] [PubMed]

68. Bigum, M.; Brogaard, L.; Christensen, T.H. Metal recovery from high-grade WEEE: A life cycle assessment. J. Hazard. Mater. 2012, 207, 8-14. [CrossRef] [PubMed]

69. Zhang, L.; Sovacool, B.K.; Ren, J.; Ely, A. The Dragon awakens: Innovation, competition, and transition in the energy strategy of the People's Republic of China, 1949-2017. Energy Policy 2017, 108, 634-644. [CrossRef]

70. The European Union Chamber of Commerce in China. Overcapacity in China: An Impediment to the Party's Reform Agenda. 2016. Available online: https://static1.squarespace.com/static/5537b2fbe4b0e49a1e30c01c/ t/56cc3017cf80a1fc057c84e4/1456222242257/Overcapacity_in_China_An_Impedim.pdf (accessed on 30 July 2018).

71. Smil, V. China's Environmental Crisis: An Enquiry into the Limits of National Development: An Enquiry into the Limits of National Development; Routledge: London, UK, 2016.

72. Chan, R.Y. Environmental attitudes and behavior of consumers in China: Survey findings and implications. J. Int. Consum. Mark. 1999, 11, 25-52. [CrossRef]

(C) 2018 by the authors. Licensee MDPI, Basel, Switzerland. This article is an open access article distributed under the terms and conditions of the Creative Commons Attribution (CC BY) license (http:/ / creativecommons.org/licenses/by/4.0/). 